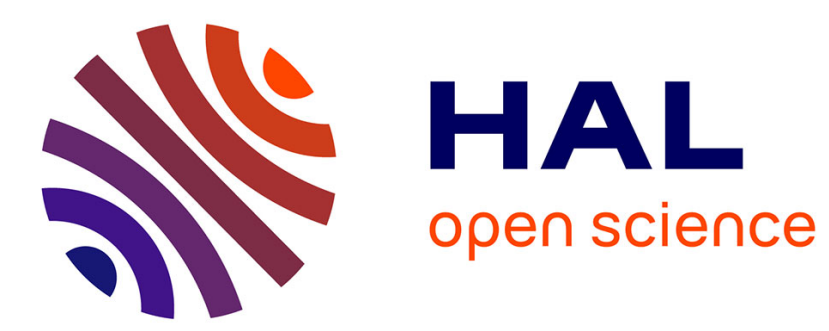

\title{
Cash holdings and the financialisation of Latin American nonfinancial corporations
}

Joel Rabinovich, Rodrigo Perez Artica

\section{To cite this version:}

Joel Rabinovich, Rodrigo Perez Artica. Cash holdings and the financialisation of Latin American nonfinancial corporations. 2020. hal-02474321

HAL Id: hal-02474321

https://hal.science/hal-02474321

Preprint submitted on 11 Feb 2020

HAL is a multi-disciplinary open access archive for the deposit and dissemination of scientific research documents, whether they are published or not. The documents may come from teaching and research institutions in France or abroad, or from public or private research centers.
L'archive ouverte pluridisciplinaire HAL, est destinée au dépôt et à la diffusion de documents scientifiques de niveau recherche, publiés ou non, émanant des établissements d'enseignement et de recherche français ou étrangers, des laboratoires publics ou privés. 


\title{
Cash holdings and the financialisation of Latin American nonfinancial corporations
}

\author{
Joel RABINOVICH*
}

Rodrigo PEREZ ARTICA ${ }^{\dagger}$

Working Paper, February 2020

\begin{abstract}
: the growth in cash holdings by non-financial corporations in emerging economies in general and Latin American in particular has received less attention compared to their peers from advanced economies. Taking into account that cash holdings contain not only cash but also short-term, interest-bearing assets, we test whether financial profitability measured by the weight of financial income over total revenues was one motive behind the increase in this type of financial asset as it is claimed in analyses of the financialisation of the firm. We use a panel of nonfinancial firms from Argentina, Brazil, Chile, Colombia, Mexico and Peru to test this hypothesis and find supporting evidence for the Brazilian case only.
\end{abstract}

Keywords: cash holdings, financialisation of the firm, Latin America.

\footnotetext{
${ }^{*}$ Economic Department, Leeds University Business School, UK and CEPN (Centre d'Economie de l'Université Paris 13), France. Email: joel.rabi@gmail.com

† Economic Department, Universidad Nacional del Sur (UNS)-Researcher at the Instituto de Investigaciones Económicas y Sociales del Sur (IIESS-UNS/Conicet), Argentina.Email: rodrigoperezartica@gmail.com
} 


\section{Introduction}

During the 2000s, Latin American economies went through a period of accelerated economic growth and buoyant financial markets, in the midst of the upward phase of the commodities prices and foreign capital inflows cycle. In spite of this favorable context, non-financial corporations' (NFCs) economic performance fell behind expectations (Economic Commission for Latin America and the Caribbean, 2014; International Monetary Fund, 2015; Manuelito \& Jiménez, 2015). Moreover, this disappointing behavior seems to linger on today.

Meanwhile, Latin American NFCs steadily increased their ratio of cash and equivalents ${ }^{1}$ to total assets mirroring a similar performance by advanced economies' corporates over the last 30 years as it is shown in Figure 1. Although substantial media and academic attention has been devoted to growing cash holdings in developed countries (Bates et al., 2009; Pinkowitz et al., 2015), the recent increase by Latin American firms has been mostly overlooked by scholars.

\section{Figure 1. Cash holdings in Latin American NFCs, 1997-2018.}

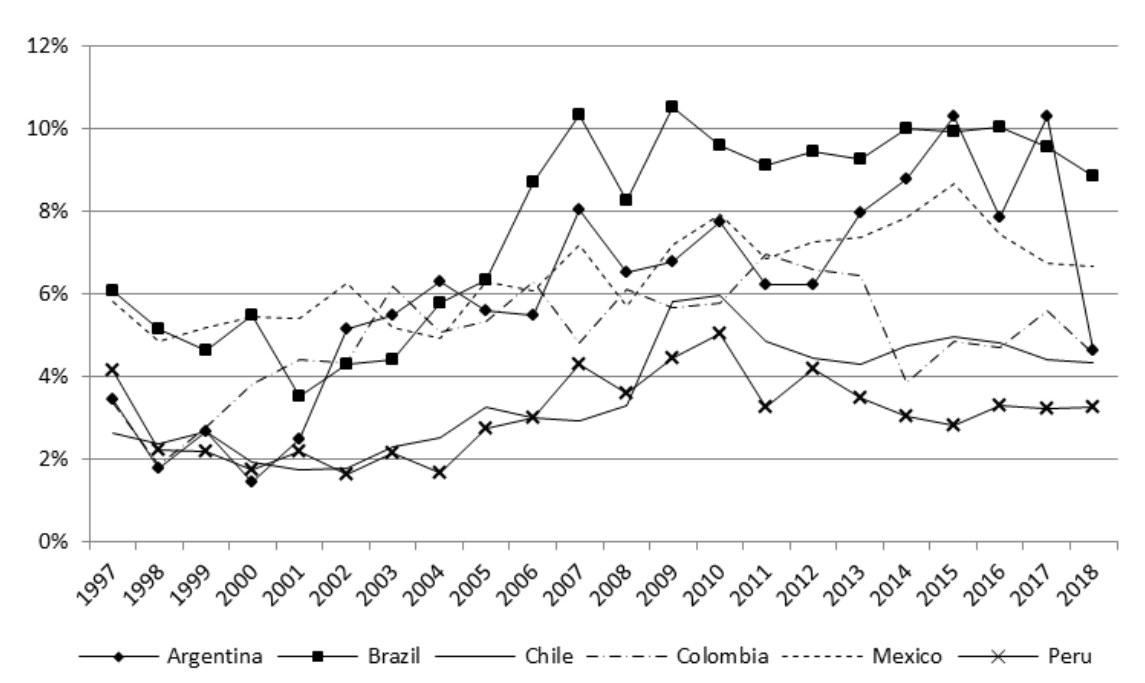

Note. Median of cash holdings calculated as cash and short-term investments (Compustat Data Item 1) over total assets (Compustat Data Item 6). Latin American nonfinancial listed firms.

Source. Compustat Global.

In the case of advanced economies, the financialisation literature traditionally linked the increase in financial assets held by NFCs to the quest for financial profits (Crotty, 2005; Krippner, 2011; Orhangazi, 2008; Stockhammer, 2004). It has only been recently that different studies, both at the macro and micro level, appeared to asses the general validity of that statement, finding mixed evidence. The case of 'cash and short-term investments' (a category that includes interest-bearing assets) is especially relevant since it has experienced one of the major increases of all financial assets (Davis, 2016; Rabinovich, 2019). Specifically for the US case, while Rabinovich (2019) rejects what he refers as the financial turn of accumulation hypothesis based on a reassessment of the measurement, composition and evolution of financial income, along with a broader analysis of assets and uses of funds, Davis (2018) finds a positive relation between cash holdings and financial

\footnotetext{
${ }^{1}$ In this article we will talk indistinctly of 'cash and equivalents', 'cash holdings' and 'cash and short-term investments'.
} 
profitability. To the best of our knowledge, the latter is the only econometric analysis on the relation between those variables. ${ }^{2}$

Surprisingly, there is no study on that relation for the case of emerging market economies even though the link may be stronger. We say this taking into account that, in the case of emerging market economies, firms have higher possibilities to carry trade (Bruno \& Shin, 2017a; Caballero, Panizza, \& Powell, 2016; Shin \& Zhao, 2013) and speculate with national currencies (Farhi \& Borghi, 2009; Rossi Júnior, 2013; Zeidan \& Rodrigues, 2013).

In this context, the objective of this paper is to estimate the determinants of cash holdings from Latin American NFCs during the last twenty years focusing on whether financial returns have been or not associated with that increase. If these variables are found to have a positive relation in our econometric exercises, it means that there is an empirical basis to claim that the yield of those financial assets is a powerful driver behind their accumulation. If they are not related, it means that the accumulation of cash and shortterm investments is independent of the search for new profitable opportunities but may be related, rather, to basic cash management.

We use annual firm-level data retrieved from Compustat Global from a sample of listed firms from six Latin American economies: Argentina, Brazil, Chile, Mexico, Peru and Colombia between 1997 and 2018. With this data, we estimate standard cash holdings equations to which we add a measure of financial profitability. The main contribution of this paper is to show that, on average, financial income is related to the increase of cash holdings for Brazilian NFCs. Moreover, these results are driven by larger firms, those above the median of financial income and the 2008-2018 period.

The remainder of the paper is organized as follows. Section 2 reviews the relation between the increase in cash holdings and the financialisation of the firm in developed and emerging economies. Sections 3, 4 and 5 present the model and hypotheses, data and stylized facts and methodology respectively. Section 6 discusses the econometric results and finally, Section 7 concludes.

\section{Cash holdings and the financialisation of the firm}

\section{a. General motives}

A motive for cash and short-term investments demand highlighted by the financialisation literature is the quest for financial profitability (Davis, 2018). Various historical reasons starting in the 1970s and the 1980s originated this shift from NFCs' more traditional activities and sources of profits. Broadly speaking, these motives can be grouped into two non-exclusive reasons.

The first highlights the different types of problems in the production sphere. Magdoff and Sweezy (1987) point towards the stagnation of the economy and the increasing difficulty to realize profits through traditional ways such as private consumption and investment. The underperformance and slowdown of aggregate demand in the 1970s are also highlighted by Davis (2016) and Crotty (2005). On top of this, Krippner (2005) emphasizes the higher degree of labor militancy at home and increased international

${ }^{2}$ Bruno and Shin (2017) and Caballero, Panizza and Powell (2016) perform similar exercises but with different empirical strategies as it will be shown later. 
competition abroad. Moreover, at the same time that NFCs were experiencing different types of difficulties in production, the financial sector presented the opposite situation creating, therefore, incentives to invest in the financial market (Orhangazi, 2008).

The second group of explanations of the shift to financial activities focuses on the internal changes experienced by NFCs in terms of power relations between managers and shareholders (Stockhammer, 2004; Tomaskovic-Devey et al., 2015). Based on the postKeynesian theory of the firm (Lavoie, 1992; Wood, 1975), scholars claim that while managers have a preference for growth, shareholders favor profits. The alignment of the former's preferences with those of shareholders was introduced by the hostile take-over movement and changes in pay structure, which resulted in NFCs becoming more rentierlike and abandoning growth-oriented priorities.

Paradoxically, the quest for financial profits linked to the increased acquisition of financial assets, or what Rabinovich (2019) defines as the financial turn of accumulation hypothesis, has been tested only indirectly (with the exception of Davis, 2018) and somewhat disconnected from the corporate finance literature on cash holdings. We say indirectly because most empirical studies focus on the effect of financial income on physical investment (capital expenditures) rather than financial investments (see, for example, Orhangazi, 2008; Stockhammer, 2004; Tori \& Onaran, 2018b, 2018a). Negative and significant values of the estimated parameters are thus interpreted as a proof of the turn to financial accumulation that crowds-out productive accumulation (Hecht, 2014; Orhangazi, 2008; Stockhammer, 2004).

However, in many cases, different types of financial assets are found to have a positive effect on investment. Davis' (2017) takes a broad definition of financial assets that includes cash and short-term investments, current receivables, other current assets (less inventories) and investments and advances and finds a positive relation with investment. A financial profit rate is found to have a positive effect on investment as well. She interprets them, respectively, as due to the greater flexibility provided by liquid financial assets to support real investment, and the possible complementarities between the financial and nonfinancial components of their business (for example, store-issued credit cards supporting the sales of non-financial products). Some paradigmatic case studies such as those carried out for Ford or General Electric have focused on that aspect of their business model (Froud et al., 2006). Other econometric studies take a narrower definition of financial assets like Auvray and Rabinovich (2019) and Hecht (2014) who consider cash and short-term investments only and find that they are positively correlated with investment.

Mainstream literature has also pointed to this direction. Cash and short-term investments may prove to be the only source of liquidity when no other access to finance is available and thus propel real operating activities and investment. Myers \& Majluf (1984) posit that when information asymmetries increase the cost of raising external capital, firms with reliable investment projects ("high" or "good" type in a typical adverse selection model) will avoid external finance. Cadsby, Frank, \& Maksimovic (1990) present a simple adverse selection model illustrating this point. This adverse selection problem produces a hierarchy or pecking order of financial sources, ordered from the least to the most expensive. When facing liquidity requirements (such as investment disbursements or debt 
repayments), firms will first resort to internal financing, then turn to debt, and finally issue equity (for a review of the pecking order theory see Frank \& Goyal, 2008).

Besides, when firms are financially constrained and cannot secure external finance, they are prone to accumulate cash and equivalents out of current cash flows to meet future investment opportunities and debt repayments (Acharya et al., 2007)

Finally, the financialisation literature also recognizes differential effects in terms of size, with bigger firms engaging more in financial activities. Orhangazi (2008) finds that financial payouts and financial income present a negative and significant effect on capital expenditures which is 50\% higher than for small firms. Davis (2017) also finds a negative and significant effect of financial payouts for larger firms.

\section{b. Emerging-markets specific motives}

While traditionally focused on developed economies, the financialisation literature has progressively broadened the scope incorporating emerging market economies (EME), usually comparing them with their developed peers (for a review see Bonizzi, 2013; Bortz \& Kaltenbrunner, 2018; Karwowski \& Stockhammer, 2017; specifically for Latin America see Abeles et al., 2018). In the case of NFCs, the motives allegedly making them move towards finance were, in many cases, also present in EME. The falling rate of profit, higher returns in the financial sector and poor macroeconomic performance are examples of them (Demir, 2007; Demir, 2009). ${ }^{3}$

As in the case of NFCs belonging to advanced economies (AE), some studies have concentrated on the impact of increased financial activity over physical investment. Demir (2009) does it for Argentinian, Mexican and Turkish listed NFCs and finds a negative and statistically significant effect of the return gap in favor of financial returns compared to fixed investment. Seo, Kim and Kim (2016), on the other hand, do not find a statistically significant effect of financial profitability on South-Korean NFCs' investment.

On top of these common explanations, scholars have highlighted some specific causes which make the quest for financial profit more significant in emerging countries. To begin with, interest rates tend to be consistently higher in these economies. This can be attributed to internal and/or external reasons. The former include factors such as higher inflation, external debt burden, current account deficits, and default history, among others (Bellas et al., 2010; Cantor \& Packer, 1996). However, even with strong internal fundamentals, EME may still need to keep interest rate differentials due to their subordinate role in the international financial system (Conti et al., 2014; Kaltenbrunner, 2015). In any case, as put by Bonizzi (2013, p. 85), "financialisation through interest income may be of particular relevance for many developing countries, since inflation and the need to encourage capital inflows (or discourage capital flight) has often induced these countries to adopt high interest rates." For instance, the relevance of high interest rates for the regular activities of EME NFCs has been such that, in Brazil, the reduction in 2013 was criticized rather than supported by the productive sector (Neumann, 2016).

Higher interest rates offer the opportunity for carry trades. Although traditionally associated with financial institutions, different authors found that in the presence of

\footnotetext{
${ }^{3}$ Changes in terms of power balances between management and shareholders, however, are more arguable. One of the most important legal forms of business in developing countries, now and before, are the business groups where ownership and management are not separated (Khanna \& Yafeh, 2007).
} 
capital controls, EME NFCs have been increasingly engaged in such activities, acting as surrogate financial intermediaries (Shin \& Zhao, 2013). NFCs have comparative advantages in bypassing capital controls compared to financial institutions mainly through intracompany loans which are classified as FDI in the balance of payments (Avdjiev et al., 2014; McCauley et al., 2013). Powell (2013) presents macroeconomic data of Mexican NFCs which suggests an increased involvement in carry trades between 2004 and 2008. Using firm-level data from 18 emerging economies, Caballero, Panizza and Powel (2016) find a positive and statistically significant impact of capital controls with regards to liquid financial assets. Bruno and Shin (2017), using also firm-level data but both from emerging and advanced economies, show that EME firms, vis-à-vis their AE peers, borrow more in dollars when they already have high cash balances and maintain a higher proportion of those funds in cash within the next 3 years. From a group of possible explanations including precautionary motives, capital expenditures, R\&D, long-term debt reduction and carry trade, the authors find evidence for the latter.

Speculative activities by EME NFCs are not only limited to carry trades. Farhi and Borghi (2009) report many cases in which financial derivatives were used to bet that their national currencies wouldn't depreciate against the dollar rather than hedging, ${ }^{4}$ and had enormous losses. Although in most cases these NFCs were exporters, therefore making sense to protect themselves from appreciation, the amounts were much higher than the volume of exports. Zeidan and Rodrigues (2013) focus on the example of a Brazilian company, Aracruz Celulose, who lost more than US $\$ 2$ billion with currency derivatives. Using a panel of 200 Brazilian NFCs which represent approximately $68 \%$ of all market capitalization in Brazil, Júnior (2013) shows that approximately 15\% of derivatives users could be classified as speculators in 2008 and 2009.

An interesting distinction can be derived from the financial activities engaged by NFCs in emerging and developed countries. In the case of the latter, case studies generally show that they are related to the provision of financing to their clients (Froud et al., 2006). Therefore, it is an activity that is dependent on their main production. In the case of NFCs belonging to emerging markets, the engagement in financial activities is also originally related in many cases with their main activity (managing foreign currency and financial derivatives due to exports) but then becomes independent of it. In this sense, it could also be argued that NFCs from EME could be more financialised than their AE peers.

Studies specifically focusing on the increase of financial assets held by Latin American firms are scarce. Pérez Artica, Brufman, \& Saguí (2018) document the increase in cash holdings and find that larger firms hold less cash, thus signaling the lower need for financial hedging as the growing amount of assets in place allow more fluid access to external finance. However, they do not take into account financialisation as one of the possible explanations. Torija Zane and Gottschalk (2018) discuss different hypothesis for the increase in financial assets, one of them carry trade, but do not test any of them empirically.

As we will detail next, a set of variables already used in the literature of cash holdings may capture some of the effects previously described (like leverage). In addition to payout which is already a standard variable, we follow Davis (2018) and include a new variable of

${ }^{4}$ Which is the original purpose of the instruments: "[h]edging is the use of financial instruments, such as futures contracts, to offset the risk in an investment portfolio" Available in https://stats.oecd.org/glossary/detail.asp?ID=1224 
financialisation in these models that capture the incentive to accumulate liquid financial assets, namely financial income.

\section{Model and hypothesis}

Based on the theoretical insights developed in Sections 2 and 3 we propose to estimate the following equation:

$$
\begin{aligned}
& \frac{\text { Cash\&St.Inv }}{\text { Assets }}_{i t}=\alpha_{0}+\alpha_{1} \frac{\text { Cash\&St.Inv }}{\text { Assets }}_{i, t-1}+\alpha_{2} \frac{\text { Financial Income }}{\text { Revenues }}_{i t}+\alpha_{3} \frac{\text { Nonfinancial profits }}{\text { Revenues }}_{i t} \\
& +\alpha_{4} \frac{\text { Capital Expenditures }}{\text { Assets }}_{\text {it }}+\alpha_{5} \frac{\text { Payouts }}{\text { Assets }} \text { it }_{j=}+\alpha_{6} \frac{\text { Leverage }}{\text { Assets }}_{i t}+\alpha_{7} \log (\text { Assets })_{i t} \\
& +\sum_{t=1997}^{t=2018} \beta_{t}+\sum_{j=1}^{j=6} \gamma_{j, t}+\varepsilon_{i t}
\end{aligned}
$$

Where $\alpha_{0 \ldots} \alpha_{7}$ are parameters, the $i$ subscript denotes the firm and the $t$ subscript denotes the time period. $\beta_{t}$ are coefficients of a set of annual time dummies, $\gamma_{j, t}$ are industryspecific trends, while $\varepsilon_{i t}$ represents nonobservable shocks.

Our dependent variable is defined as cash and short-term investment (Compustat Data Item 1) over total assets (Compustat Data Item 6). This is a standard variable used in the literature (Bruno \& Shin, 2017; Caballero et al., 2016; Shin \& Zhao, 2013). The numerator includes both immediately negotiable medium of exchange or any instruments normally accepted by banks for deposit and interest-bearing assets may be converted to cash within a relatively short period (CDs, money market accounts, high-yield savings accounts, government bonds and Treasury bills).

We regress this cash and short-term investments ratio on a set of independent firm-level regressors intended to capture the effect of financial income discussed in Section 3 and control for a set of theoretically relevant control variables that take into account the main sources and uses of funds available for the firm. We describe each regressor below.

Financial income (Compustat Data Item 62) comprises interest and dividends from investment securities and interest from securities of national and local governments. We use the ratio of financial income to total revenue (Compustat Data Item 12) to capture the relevance of these types of activities over the total income of the firm.

The hypothesis we want to test is the following: if firms are actively engaging in financial and speculative activities, then the $\alpha_{2}$ parameter in Equation (1) should be positive and statistically significant. If not, then the variable should not be significant.

In an article with a very similar objective than ours, Davis (2018) also used financial income as an explanatory variable. We believe this is a better choice than other alternatives found in the literature. Bruno and Shin (2017) calculate carry trade as the difference between the domestic money market rate and the US money market rate divided by a measure of volatility. Caballero et al (2016) also take a differential between rates. In both cases, a country-level measure is imputed to each firm besides what she is actually earning. By choosing a measure that captures the proceeds from financial investment for each firm, we avoid that problem. 
Moreover, as we noted in the previous section, the financial income coming from carry trades and speculation is, in most of the cases, an independent activity from the main one in NFCs. This is different from lending to clients and its relevance is not only theoretical but also empirical: it affects how information is presented in Financial Statements. While financial income related to operating activities might be consolidated in total revenue (Rabinovich, 2019), the financial (nonoperating) income we are studying is not. This is an additional point in favor of using financial income in our study.

In terms of our control variables, firms save cash out of their cash flows to prevent future liquidity shortages (Acharya, Almeida \& Campello, 2004). Consequently, we control for operating income, a variable we call Nonfinancial profits, and we measure it as the ratio of operating income before depreciation (Compustat Data Item 13) net of financial income to total assets. We expect the corresponding parameter to be positive.

One of the main uses of funds is capital expenditures. The fact that firms will mostly turn to their cash holdings in the first place when incurring in capital expenditures has been highlighted by different theoretical strands, both mainstream (Bates et al., 2009; Myers \& Majluf, 1984) and nonmainstream (Eichner, 1976; Wood, 1975). Capital expenditures (Compustat Data Item 128) are measured as a proportion of total assets, and we expect its parameter to be negative.

Payouts are measured as dividends paid (Compustat Data Item 127) to total assets. Similarly to capital expenditures, firms will use their cash holdings when deciding to distribute to their shareholders. In addition, firms that pay dividends tend to be less risky and have greater access to capital markets, thus reducing the need for precautionary cash holdings (Bates et al., 2009; Hadlock \& Pierce, 2010). Therefore, we also expect this parameter to be negative.

Leverage is measured as the ratio of the book value of total liabilities (Compustat Data Item 181) to total assets. This is a measure of the extent to which firms access to credit and debt markets and therefore relevant for cash holding management. We expect this coefficient to be negative, reflecting a lower need to hedge against financial constraints.

Finally, we expect larger firms to show economies of scale for holding cash (Opler et al., 1999), and also have easier access to capital markets, since they have more collateral to offer (Bates et al., 2009). Therefore, they have a lower need to hold cash. Size is measured as the natural logarithm of the book value of total assets.

\section{Data and stylized facts}

We extracted our data from Compustat Global database that includes information, among others, on Latin American publicly listed firms' Balance Sheet, Income Statement and Cash Flow Statement. Compustat provides standardized and consolidated firm-level information for listed companies that we organize according to the Standard Industrial Classification (SIC) of each corporation excluding financial firms identified by the primary codes from 6000 to 6799. Working with consolidated information represents an advantage since all subsidiaries are included, even the financial ones. We use annual information for all active and inactive, publicly listed NFCs in Argentina, Brazil, Chile, Colombia, Mexico and Peru between 1997 and 2018. 
As it is usually the case, our firm-level data requires some treatment before we can apply econometric techniques. In terms of missing values, we eliminate those firms with no info or nil values in net property, plant and equipment, net revenue, total assets and liabilities and liquidity. We also drop firms with no information on profits and only take firms that have at least five consecutive observations for the dependent variable, something required for our Generalized Method of Moments (GMM) econometric technique. In terms of extreme values, we winsorize all variables at the upper and lower $0.5 \%$ of each variable's distribution (Bond et al., 2003). Table 1 provides the basic descriptive statistics of the data we will be using.

\section{Table 1. Descriptive statistics}

\begin{tabular}{lllllll} 
Variable & Observations & Mean & Std. Dev. & Median & Min. & Max. \\
\hline Cash\&St.Inv & 11,733 & 0.088909 & 0.096267 & 0.05721 & 0.000095 & 0.560221 \\
Financial Income & 11,733 & 0.022191 & 0.049535 & 0.006702 & 0 & 0.526965 \\
Nonfinancial profits & 11,733 & 0.100174 & 0.100046 & 0.096515 & -0.34031 & 0.5201291 \\
Capital Expenditures & 11,733 & 0.050366 & 0.049151 & 0.037732 & 0 & 0.3176812 \\
Payouts & 11,733 & 0.023424 & 0.043727 & 0.007313 & 0 & 0.3265569 \\
Leverage & 11,733 & 0.568462 & 0.434042 & 0.516928 & 0.044472 & 4.727881 \\
Log(Assets) & 11,733 & 6.171108 & 1.890264 & 6.205542 & 0 & 11.71489
\end{tabular}

In Figure 1 we already showed the increase in cash holdings during the period we are analyzing. Figure 2 further indicates that this increase has been shared by all industry groups: Primary (SIC codes 0100-1499), Construction (1500-1799), Manufacturing (20003999), Transportation, Communications, Electric, Gas and Sanitary service (4000-4999), Whosale and Retail Trade (5000-5999) and Services (7000-8999). Moreover, the trajectory is similar to that of countries: an increase until the financial crisis followed either by a decrease or stagnation. However, the primary sector exhibits an impressive increase that reaches a cash-to-assets ratio of $18 \%$ in 2007 followed by services which reached $14 \%$. In both cases, the ratio decreases afterward. In a similar vein, Bruno and Shin $(2017$, p. 720 ) indicate that the oil and gas sector accounted for $23 \%$ of the total issuance of dollar bonds, much of which would be held as cash and short-term investments.

Figure 2. Cash holdings in selected sectors, 1997-2018.

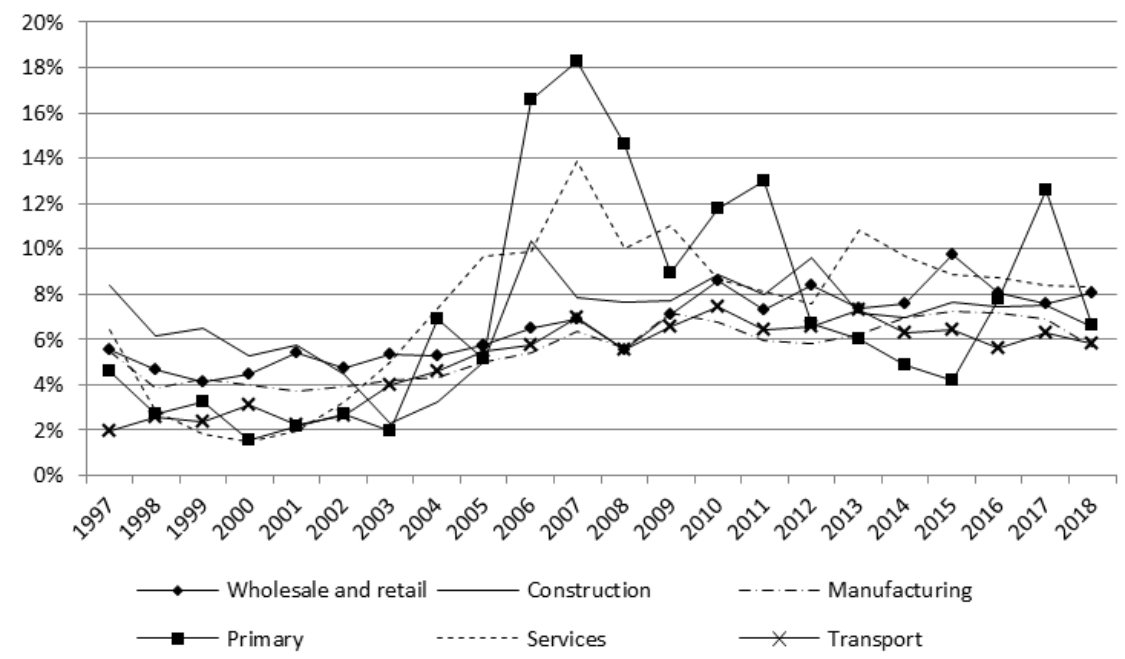


Note. Median of cash holdings calculated as cash and short-term investments (Compustat Data Item 1) over total assets (Compustat Data Item 6). Latin American nonfinancial listed firms from selected sectors.

Source. Compustat Global.

The question we are addressing is whether these movements in cash holdings have been linked or not to a quest for financial profitability. Figure 3 presents, therefore, the evolution of our main variable of interest: financial income. Countries display a similar pattern with a decreasing proportion until the beginning of the 2000s followed by an upward phase until the crisis and then a new declining trend (except for Argentina). ${ }^{5}$

This general pattern is also followed at the industry level. It is interesting to see that the impressive cash holdings in the primary sector do not have a counterpart in terms of financial income. More generally, both Figures indicate that financial income does not seem to have played a relevant role in the overall revenue structure of Latin American non-financial firms, being $3 \%$ at most in the case of Brazil. Nevertheless, besides these low levels, both variables seem to share a common trend especially since the 2000 s with an upward trend until the crisis followed by a stagnant or declining one.

Part of this common trend is a logical outcome of the fact that higher cash holdings will generate higher financial income. The question we are posing, however, is rather the reverse. Was the quest for financial profitability that triggered the accumulation of those liquid financial assets? In the next section, we describe the methodology to answer it.

Figure 3. Financial income in Latin American NFCs, 1997-2018.

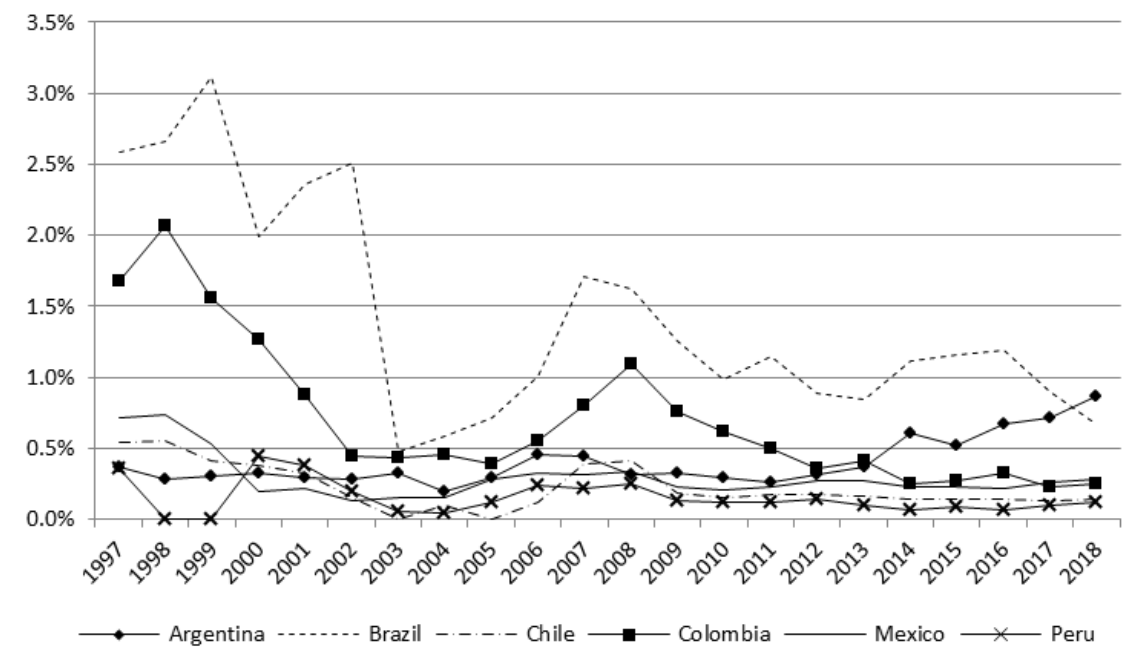

Note. Median of financial income (Compustat Data Item 62) calculated as proportion of total revenue (Compustat Data Item 12). Latin American nonfinancial listed firms.

Source. Compustat Global.

${ }^{5}$ Interestingly, this evolution largely tracks the US effective funds rate. 
Figure 4. Financial Income in selected sectors, 1997-2018.

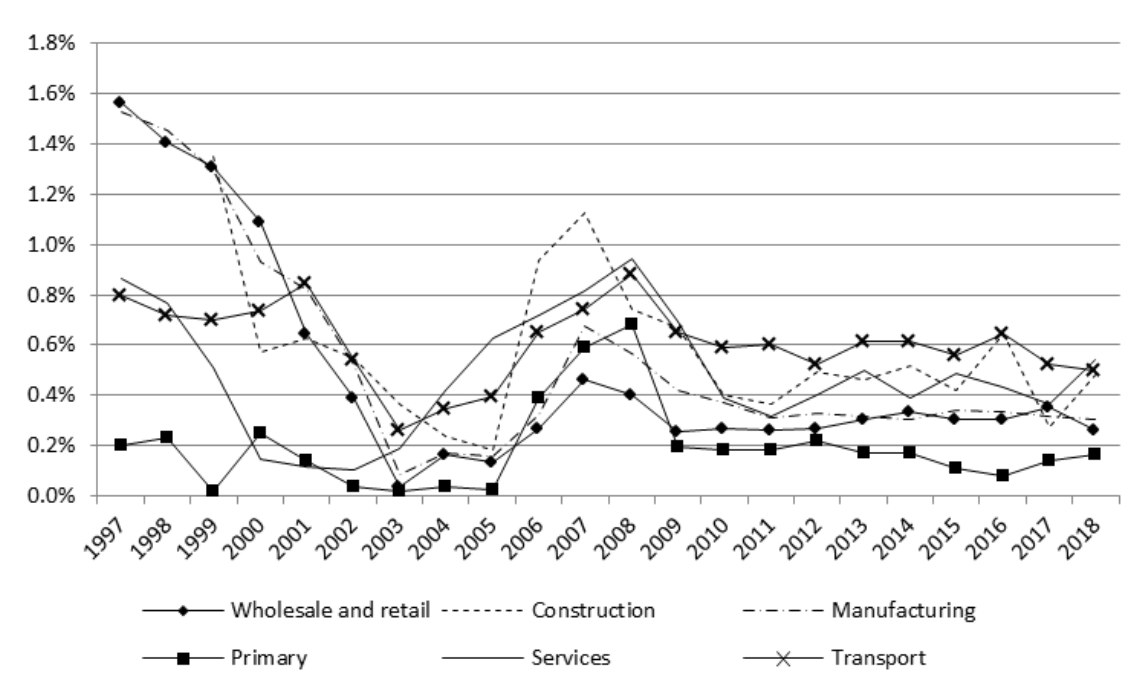

Note. Median of financial income (Compustat Data Item 62) calculated as proportion of total revenue (Compustat Data Item 12). ). Latin American nonfinancial listed firms from selected sectors.

Source. Compustat Global.

\section{Methodology}

Endogeneity arising due to unobservable individual heterogeneity is a well-known problem associated with microeconomic data, rendering ordinary least squares (OLS) to be inconsistent as it requires explanatory variables to be uncorrelated with the error term. This is also the case with the within groups estimator (Pindado \& Requejo, 2015). Although the transformation into deviations from the means eliminates constant unobservable heterogeneity, taking variables as strictly exogenous in microeconomic decisions is a strong assumption. Moreover, in dynamic panel models, the lag of the dependent variable is, by definition, correlated with the error term. The Within estimator will be biased and its consistency depends upon $T$ being large (Nickell, 1981).

On the other hand, instrumental variables (IV) methods can overcome endogeneity problems as long as the chosen instrument is also uncorrelated with the error term. GMM is a particular IV method where more than one instrument for each explanatory variable can be used. Moreover, rather than looking for instruments outside the model, GMM offers the possibility to use the lags of explanatory variables as instruments. Not only these instruments naturally contain more information than variables outside the model but also, as it was proved by Arellano and Bond (1991) and Blundell and Bond (1998), they are uncorrelated with the error term.

Arellano and Bond (1991) proposed a GMM procedure that is more efficient than that of Anderson and Hsiao (1981). The latter consisted on first differencing the model to remove the individual effects and then using the second lag of the dependent variable as an instrument for the first lag which would not be correlated with the error as long as it is not serially correlated. The procedure proposed by Arellano and Bond (1991) uses additional instruments based on the orthogonality condition that exists between lagged values of the right-hand side variables and the error term. The estimator has one-step (for 
homoscedastic disturbances) and two-step variants (for heteroscedastic disturbances). Although the latter is more general, the standard errors are usually low. Nevertheless, the finite-sample correction derived by Windmeijer (2005) adjusts the standard errors for heteroscedasticity making the two-step more efficient than one-step.

Finally, a problem with the original Arellano-Bond (1991) estimator is that lagged levels tend to be poor instruments for first differences. Arellano and Bover (1995) showed that, under certain conditions, when the original equations in levels were added to the system, the efficiency could be increased. Later, Blundell and Bond (1998) provided the necessary assumptions for the augmented estimator more precisely. The new instruments will be valid as long as the stationarity condition is fulfilled: the correlation between the explanatory variables and the unobserved effects does not change over time.

System GMM can generate quite a great number of instruments, something that, although does not compromise consistency, can move it away from the asymptotic ideal and overfits endogenous variables failing to expunge their endogenous components (Roodman, 2009, p. 98). In order to reduce the number of instruments, we use one instrument for each variable and lag distance instead of one for each time period, variable and lag distance (we collapse the instrument set).

Besides the lag of cash holdings, variables included are in all cases contemporaneous and therefore we treat them as endogenous, except dummy variables. For instance, as we have already mentioned, financial income is also an endogenous variable as large cash holdings may generate large financial income (reverse causality). Our methodology allows us to deal with this issue when deciding the structure of lags that will be used as instruments: predetermined variables allow to use the first lag as an instrument while endogenous demands starting by the second lag.

The correct specification of the model is evaluated by means of 3 tests. The first addresses serial correlation in the disturbance term. Since the model takes first differences, it could have first order but not second order serial correlation in the residuals. The $m_{1}$ and $m_{2}$ statistics test that ( $\operatorname{ar} 1 \mathrm{p}$ and $\operatorname{ar} 2 \mathrm{p}$ in the tables are the $\mathrm{p}$-values associated with those tests). The final test addresses endogeneity. The Hansen $J$ statistic of overidentifying restrictions evaluates the validity of instruments by testing the correlation between instruments and the error term.

\section{Results}

\section{a. General results}

Table 2 shows the results of the estimation of equations 1 for the complete sample of firms as well as for each national sub-sample. To assure that the autocorrelation and overidentification tests are passed, we include two lags for each variable and therefore, in all cases, our model is well-specified. All estimations include year and industry fixed effects. The specification comprising all firms includes country fixed effects.

In terms of our main variable of interest, financial income, we find supporting evidence of a positive effect over cash and short-term investments holdings. Nevertheless, this result seems to be driven by Brazil. Results are statistically significant at the $1 \%$ level only for that country and non-negligible economically with an elasticity of $17 \%$. The Brazilian 
result is consistent with the previous literature that found speculative activities carried by those firms (Farhi \& Borghi, 2009; Rossi Júnior, 2013) as well as case studies (Zeidan \& Rodrigues, 2013). For the remaining countries, financial income is not statistically significant or even negative.

Moving to the other variables, the lagged value of liquidity holdings is statistically significant at the $1 \%$ level with elasticities closer to $60 \%$ in all cases except Colombia where it is higher. The second lag is also significant for the whole sample although driven mainly by Brazil, again at the $1 \%$ level. These results confirm the existence of a dynamic process in terms of the decisions regarding cash holdings, and therefore the importance of using a dynamic model. Additionally, in all cases it indicates positive feedbacks from previous decisions.

Not only the lagged value of liquidity but also other variables are robust across the whole sample and countries. First, nonfinancial profitability has a positive and statistically significant effect for Argentina, Brazil, Peru and Colombia showing that firms retain part of the internally generated cash flows. Second, a result that is robust across all countries is the negative and statistically significant value of investment. This indicates that whenever firms decide to invest they will turn to their internal cash holdings: all countries have a negative and statistically significant effect which is close to $20 \%$ in most cases (except Colombia). Also in terms of capital expenditures, for the whole sample and Mexico only, the second lag has a positive effect. This implies that even though firms turn to the cash balances for investment decisions, over time they intend to recover part of that cash.

Other variables such as leverage and size are non-robust and less significant. Regarding the former, we find negative and statistically significant results for the whole sample (in line with Al-Najjar, 2013), although the sign is non-stable. Results in terms of size are similar to those of leverage: we find statistically significant values for the whole sample which nevertheless flip in the different lags. The overall long-run effect for these two variables is therefore close to 0 .

In Table 3 we evaluate whether our results for financial income are driven by specific sectors. To that end and based on the findings of previous works on higher speculating activity for those firms with higher exchange rate exposure and export activity (Farhi \& Borghi, 2009; Rossi Júnior, 2013), we interact the financial income variable with a sectoral dummy for the tradable sector (manufacturing and primary). Our results replicate those obtained in Table 3 since again it is Brazil where we obtain significant results and we do find additional effects for the tradable sector.

Finally, Tables 4 and 5 present the results for financial income and leverage for two periods: 1997-2007 and 2008-2018, before and after the Financial Crisis. As it was highlighted in Figures 1 and 2, the highest increase in cash holdings was verified on the eve to the crisis, after that, both cash holdings and financial income stabilize or slightly decrease. However, our results indicate that the aforementioned surge in cash holdings in the first period does not seem to be related to financial profitability. The results obtained in previous tables for Brazil or the whole sample disappear.

On the contrary, it is only for the last period that we obtain positive results for that country. This is consistent, nevertheless with Bruno and Shin's (2017) finding that EME firms use of bond proceeds for cash saving in driven mainly by the post- 2007 when the 
demand for high-yield corporate bonds surged. Moreover, data built by Fernández et al (2016) show that all countries considered in our study except Colombia increased their controls in the capital account in the period starting after the Financial Crisis. Taking this into account, our results are therefore consistent with Caballero et al (2016) findings that closer capital accounts increase the likelihood that the proceeds of foreign currency bond issuances are kept in liquid financial assets when facing a positive spread between the local deposit rate and foreign currency borrowing costs.

Summing up, firms tend to hold more cash when they are more profitable and collect larger internal funding and decrease their cash holdings when they carry out capital expenditures. In terms of financial profitability, our evidence points mainly towards Brazil in the 2008-2018 period, both in terms of statistical significance and economic relevance. We will next test the robustness of these results and further dig into them. 
Table 2. Estimation results based on equation (1). Period: 1997-2018.

\begin{tabular}{|c|c|c|c|c|c|c|c|}
\hline $\begin{array}{c}\text { Dependent } \\
\text { variable:Cash\&St.Inv } \mathrm{i}, \mathrm{t}\end{array}$ & $\begin{array}{c}\text { All } \\
\text { countries }\end{array}$ & Argentina & Brazil & Chile & Mexico & Peru & Colombia \\
\hline Cash\&St.Invi,t-1 & $\begin{array}{l}0.623^{* * *} \\
(0.026)\end{array}$ & \begin{tabular}{|l}
$0.587^{* * *}$ \\
$(0.103)$
\end{tabular} & $\begin{array}{l}0.611^{* * *} \\
(0.042)\end{array}$ & $\begin{array}{l}0.496^{* * *} \\
(0.049)\end{array}$ & $\begin{array}{l}0.697^{* * *} \\
(0.082)\end{array}$ & \begin{tabular}{|l}
$0.581^{* * *}$ \\
$(0.077)$
\end{tabular} & $\begin{array}{l}0.888^{* * *} \\
(0.117)\end{array}$ \\
\hline Cash\&St.Invi,t-2 & $\begin{array}{l}0.049^{* *} \\
(0.025)\end{array}$ & $\begin{array}{l}0.056 \\
(0.094)\end{array}$ & $\begin{array}{l}0.110^{* * *} \\
(0.037)\end{array}$ & $\begin{array}{l}-0.024 \\
(0.039)\end{array}$ & $\begin{array}{l}-0.004 \\
(0.079)\end{array}$ & $\mid \begin{array}{l}0.050 \\
(0.053)\end{array}$ & $\begin{array}{l}-0.073 \\
(0.096)\end{array}$ \\
\hline Cash\&St.Invi,t-3 & $\begin{array}{l}0.000 \\
(0.017)\end{array}$ & $\begin{array}{l}0.023 \\
(0.047)\end{array}$ & $\begin{array}{l}0.034 \\
(0.026)\end{array}$ & $\begin{array}{l}-0.007 \\
(0.037)\end{array}$ & $\begin{array}{l}-0.020 \\
(0.045)\end{array}$ & $\mid \begin{array}{l}-0.083 \\
(0.057)\end{array}$ & \\
\hline Financial Income $e_{i, t}$ & $\begin{array}{l}0.116^{* *} \\
(0.049)\end{array}$ & $\begin{array}{l}0.059 \\
(0.147)\end{array}$ & $\begin{array}{l}0.188^{* * *} \\
(0.059)\end{array}$ & $\begin{array}{l}0.100 \\
(0.088)\end{array}$ & $\begin{array}{l}0.165 \\
(0.282)\end{array}$ & $\mid \begin{array}{l}0.109 \\
(0.080)\end{array}$ & $\begin{array}{l}0.123 \\
(0.085)\end{array}$ \\
\hline Financial Income $e_{i, t-1}$ & $\begin{array}{l}-0.048 \\
(0.036)\end{array}$ & $\begin{array}{l}0.084 \\
(0.072)\end{array}$ & $\begin{array}{l}-0.002 \\
(0.044)\end{array}$ & $\begin{array}{l}0.069 \\
(0.078)\end{array}$ & $\begin{array}{l}-0.278 \\
(0.199)\end{array}$ & $\mid \begin{array}{l}-0.039 \\
(0.079)\end{array}$ & $\begin{array}{l}-0.018 \\
(0.109)\end{array}$ \\
\hline Financial Income $e_{i, t-2}$ & $\begin{array}{l}-0.001 \\
(0.021)\end{array}$ & $\begin{array}{l}0.053 \\
(0.067)\end{array}$ & $\begin{array}{l}0.015 \\
(0.027)\end{array}$ & $\begin{array}{l}-0.108^{* *} \\
(0.050)\end{array}$ & $\begin{array}{l}-0.105 \\
(0.138)\end{array}$ & $\mid \begin{array}{l}-0.026 \\
(0.055)\end{array}$ & \\
\hline Nonfinancial profits $\mathrm{i}_{\mathrm{i}, \mathrm{t}}$ & $\begin{array}{l}0.020 \\
(0.060)\end{array}$ & $\begin{array}{l}0.176^{* *} \\
(0.073)\end{array}$ & $\begin{array}{l}0.086 \\
(0.058)\end{array}$ & $\begin{array}{l}0.144 \\
(0.092)\end{array}$ & $\begin{array}{l}0.057 \\
(0.087)\end{array}$ & $\mid \begin{array}{l}0.176^{* * *} \\
(0.045)\end{array}$ & $\begin{array}{l}0.221^{* * *} \\
(0.084)\end{array}$ \\
\hline Nonfinancial profitsi,t-1 & $\begin{array}{l}-0.024 \\
(0.037)\end{array}$ & $\begin{array}{l}0.041 \\
(0.054)\end{array}$ & $\begin{array}{l}0.102^{* *} \\
(0.041)\end{array}$ & $\begin{array}{l}-0.147^{* *} \\
(0.068)\end{array}$ & $\begin{array}{l}-0.001 \\
(0.124)\end{array}$ & $\mid \begin{array}{l}0.039 \\
(0.049)\end{array}$ & $\begin{array}{l}-0.086 \\
(0.122)\end{array}$ \\
\hline Nonfinancial profits $s_{i, t-2}$ & $\begin{array}{l}-0.020 \\
(0.018)\end{array}$ & $\begin{array}{l}0.056 \\
(0.043)\end{array}$ & $\begin{array}{l}0.013 \\
(0.027)\end{array}$ & $\begin{array}{l}-0.011 \\
(0.040)\end{array}$ & $\begin{array}{l}-0.136^{* *} \\
(0.054)\end{array}$ & $\mid \begin{array}{l}-0.039 \\
(0.035)\end{array}$ & \\
\hline Capital Expendituresi,t & $\begin{array}{l}-0.251^{* * *} \\
(0.044)\end{array}$ & $\begin{array}{l}-0.176^{*} \\
(0.110)\end{array}$ & $\begin{array}{l}-0.203^{* * *} \\
(0.039)\end{array}$ & $\begin{array}{l}-0.203^{*} \\
(0.111)\end{array}$ & $\begin{array}{l}-0.218^{* * *} \\
(0.081)\end{array}$ & $\mid \begin{array}{l}-0.118^{*} \\
(0.067)\end{array}$ & $\begin{array}{l}-0.256^{* *} \\
(0.103)\end{array}$ \\
\hline Capital Expenditures $\mathrm{s}_{\mathrm{i}, \mathrm{t}-1}$ & $\begin{array}{l}-0.034 \\
(0.022)\end{array}$ & $\begin{array}{l}-0.007 \\
(0.059)\end{array}$ & $\begin{array}{l}-0.022 \\
(0.029)\end{array}$ & $\begin{array}{l}0.041 \\
(0.037)\end{array}$ & $\begin{array}{l}0.010 \\
(0.075)\end{array}$ & $\mid \begin{array}{l}-0.030 \\
(0.050)\end{array}$ & $\begin{array}{l}0.058 \\
(0.115)\end{array}$ \\
\hline Capital Expendituresi,t-2 & $\begin{array}{l}0.047^{* *} \\
(0.020)\end{array}$ & $\begin{array}{l}0.071 \\
(0.049)\end{array}$ & $\begin{array}{l}0.039 \\
(0.031)\end{array}$ & $\begin{array}{l}-0.010 \\
(0.031)\end{array}$ & $\begin{array}{l}0.048 \\
(0.061)\end{array}$ & $\mid \begin{array}{l}0.145^{* *} \\
(0.059)\end{array}$ & \\
\hline Payouts $_{\mathrm{i}, \mathrm{t}}$ & $\begin{array}{l}0.056 \\
(0.077)\end{array}$ & $\begin{array}{l}-0.037 \\
(0.176)\end{array}$ & $\begin{array}{l}-0.092 \\
(0.115)\end{array}$ & $\begin{array}{l}0.028 \\
(0.106)\end{array}$ & $\begin{array}{l}0.214 \\
(0.159)\end{array}$ & $\mid \begin{array}{c}-0.153^{*} \\
(0.092)\end{array}$ & $\begin{array}{l}-0.115 \\
(0.550)\end{array}$ \\
\hline Payoutsi,t-1 & $\begin{array}{l}0.051 \\
(0.041)\end{array}$ & $\begin{array}{l}-0.065 \\
(0.193)\end{array}$ & $\begin{array}{l}-0.049 \\
(0.089)\end{array}$ & $\begin{array}{l}0.066 \\
(0.050)\end{array}$ & $\begin{array}{l}0.108 \\
(0.208)\end{array}$ & $\mid \begin{array}{l}0.153^{* *} \\
(0.067)\end{array}$ & $\begin{array}{l}0.048 \\
(0.503)\end{array}$ \\
\hline Payoutsi,t-2 & $\begin{array}{l}-0.002 \\
(0.033)\end{array}$ & $\begin{array}{l}-0.084 \\
(0.091)\end{array}$ & $\begin{array}{l}0.019 \\
(0.059)\end{array}$ & $\begin{array}{l}-0.085^{*} \\
(0.045)\end{array}$ & $\begin{array}{l}0.047 \\
(0.123)\end{array}$ & $\mid \begin{array}{l}0.129^{*} \\
(0.076)\end{array}$ & \\
\hline Leverage $_{\mathrm{i}, \mathrm{t}}$ & $\begin{array}{l}-0.048^{* * *} \\
(0.019)\end{array}$ & $\begin{array}{l}0.021 \\
(0.044)\end{array}$ & $\begin{array}{l}-0.011 \\
(0.018)\end{array}$ & $\begin{array}{l}0.007 \\
(0.061)\end{array}$ & $\begin{array}{l}-0.095^{* *} \\
(0.048)\end{array}$ & $\mid \begin{array}{l}-0.044 \\
(0.049)\end{array}$ & $\begin{array}{l}-0.049 \\
(0.052)\end{array}$ \\
\hline Leverage $_{\mathrm{i}, \mathrm{t}-1}$ & $\begin{array}{l}0.088^{*} \\
(0.049)\end{array}$ & $\begin{array}{l}0.020 \\
(0.040)\end{array}$ & $\begin{array}{l}0.004 \\
(0.040)\end{array}$ & $\begin{array}{l}-0.116 \\
(0.107)\end{array}$ & $\begin{array}{l}0.167^{* * *} \\
(0.048)\end{array}$ & $\mid \begin{array}{l}0.009 \\
(0.041)\end{array}$ & $\begin{array}{l}-0.067 \\
(0.058)\end{array}$ \\
\hline Leverage $e_{i, t-2}$ & $\begin{array}{l}-0.016^{* *} \\
(0.007)\end{array}$ & $\begin{array}{l}-0.022 \\
(0.024)\end{array}$ & $\begin{array}{l}-0.014^{* *} \\
(0.007)\end{array}$ & $\begin{array}{l}-0.010 \\
(0.020)\end{array}$ & $\begin{array}{l}-0.034 \\
(0.027)\end{array}$ & $\mid \begin{array}{l}0.019 \\
(0.025)\end{array}$ & \\
\hline $\log (\text { Assets })_{\mathrm{I}, \mathrm{t}}$ & $\begin{array}{l}0.040^{* * *} \\
(0.012)\end{array}$ & $\begin{array}{l}0.013 \\
(0.015)\end{array}$ & $\begin{array}{l}0.024^{*} \\
(0.014)\end{array}$ & $\begin{array}{l}0.017 \\
(0.029)\end{array}$ & $\begin{array}{l}0.053^{* *} \\
(0.027)\end{array}$ & $\mid \begin{array}{l}0.008 \\
(0.024)\end{array}$ & $\begin{array}{l}0.021 \\
(0.023)\end{array}$ \\
\hline $\log (\text { Assets })_{\mathrm{I}, \mathrm{t}-1}$ & $\begin{array}{l}-0.075^{* * *} \\
(0.027)\end{array}$ & $\begin{array}{l}-0.019 \\
(0.022)\end{array}$ & $\begin{array}{l}-0.028 \\
(0.022)\end{array}$ & $\begin{array}{l}-0.001 \\
(0.043)\end{array}$ & $\begin{array}{l}-0.079^{*} \\
(0.047)\end{array}$ & $\mid \begin{array}{l}-0.012 \\
(0.029)\end{array}$ & $\begin{array}{l}0.005 \\
(0.021)\end{array}$ \\
\hline $\log (\text { Assets })_{\mathrm{l}, \mathrm{t}-2}$ & $\begin{array}{l}0.003 \\
(0.004)\end{array}$ & $\begin{array}{l}0.003 \\
(0.017)\end{array}$ & $\begin{array}{l}0.002 \\
(0.009)\end{array}$ & $\begin{array}{l}-0.009 \\
(0.007)\end{array}$ & $\begin{array}{l}-0.002 \\
(0.012)\end{array}$ & $\begin{array}{l}0.003 \\
(0.010)\end{array}$ & \\
\hline N. obs & 11,733 & 1,075 & 4,672 & 2,441 & 1,744 & 1,306 & 532 \\
\hline N. firms & 883 & 75 & 374 & 173 & 130 & 88 & 43 \\
\hline Instruments & 69 & 62 & 63 & 64 & 64 & 64 & 48 \\
\hline $\operatorname{ar} 1 p$ & 0.000 & 0.000 & 0.000 & 0.000 & 0.000 & 0.000 & 0.004 \\
\hline $\operatorname{ar} 2 \mathrm{p}$ & 0.507 & 0.548 & 0.478 & 0.649 & 0.163 & 0.920 & 0.433 \\
\hline hansen & 0.683 & 0.698 & 0.305 & 0.539 & 0.256 & 0.922 & 0.992 \\
\hline
\end{tabular}

Estimations are all obtained by the Arellano-Bond two-step difference GMM. All instruments include up to four year lags. ar1p and ar2p are Arellano-Bond test of first order and second order autocorrelation in the errors. hansen is the HansenSargan test of overidentifying restrictions for all instruments. Year and sectoral dummies included in all cases. Country dummies included for the whole sample estimation. P-values are reported for all tests. * indicates significance at $10 \%,{ }^{* *}$ significance at $5 \%$ and ${ }^{* * *}$ significance at $1 \%$. 
Table 3. Estimation results based on equation (1) with tradable sector interaction. Period: 1997-2018.

\begin{tabular}{|c|c|c|c|c|c|c|c|}
\hline $\begin{array}{c}\text { Dependent } \\
\text { variable:Cash\&St.Inv }{ }_{i, t}\end{array}$ & $\begin{array}{c}\text { All } \\
\text { countries }\end{array}$ & Argentina & Brazil & Chile & Mexico & Peru & Colombia \\
\hline Cash\&St.Invi,t-1 & $\begin{array}{l}0.625^{* * *} \\
(0.026)\end{array}$ & \begin{tabular}{|l}
$0.571^{* * *}$ \\
$(0.095)$
\end{tabular} & \begin{tabular}{|l}
$0.600^{* * *}$ \\
$(0.047)$
\end{tabular} & \begin{tabular}{|l}
$0.444^{* * *}$ \\
$(0.066)$
\end{tabular} & $\begin{array}{l}0.700^{* * *} \\
(0.106)\end{array}$ & \begin{tabular}{|l}
$0.574^{* * *}$ \\
$(0.089)$
\end{tabular} & \begin{tabular}{|l}
$0.894^{* * *}$ \\
$(0.207)$
\end{tabular} \\
\hline Cash\&St.Inv $v_{i, t-2}$ & $\begin{array}{l}0.050^{* *} \\
(0.022)\end{array}$ & $\begin{array}{l}0.031 \\
(0.101)\end{array}$ & $\begin{array}{l}0.106^{* * *} \\
(0.036)\end{array}$ & $\begin{array}{l}-0.056 \\
(0.049)\end{array}$ & $\begin{array}{l}0.025 \\
(0.078)\end{array}$ & $\begin{array}{l}0.039 \\
(0.062)\end{array}$ & $\begin{array}{l}-0.088 \\
(0.123)\end{array}$ \\
\hline Cash\&St.Inv $v_{i, t-3}$ & $\begin{array}{l}-0.001 \\
(0.017)\end{array}$ & $\begin{array}{l}0.004 \\
(0.045)\end{array}$ & $\mid \begin{array}{l}0.034 \\
(0.027)\end{array}$ & $\begin{array}{l}-0.058 \\
(0.060)\end{array}$ & $\begin{array}{l}0.013 \\
(0.050)\end{array}$ & $\begin{array}{l}-0.121^{* * *} \\
(0.046)\end{array}$ & \\
\hline Financial Income $e_{i, t}$ & $\begin{array}{l}0.056 \\
(0.049)\end{array}$ & $\begin{array}{l}-0.056 \\
(0.203)\end{array}$ & $\mid \begin{array}{l}0.131^{* *} \\
(0.066)\end{array}$ & $\begin{array}{l}-0.008 \\
(0.157)\end{array}$ & $\begin{array}{l}0.023 \\
(0.265)\end{array}$ & $\mid \begin{array}{l}-0.005 \\
(0.195)\end{array}$ & $\mid \begin{array}{l}0.148 \\
(0.123)\end{array}$ \\
\hline Financial Income $e_{i, t-1}$ & $\begin{array}{l}-0.083^{*} \\
(0.043)\end{array}$ & $\begin{array}{l}0.082 \\
(0.153)\end{array}$ & $\mid \begin{array}{l}-0.034 \\
(0.048)\end{array}$ & $\begin{array}{l}-0.066 \\
(0.086)\end{array}$ & $\begin{array}{l}-0.207 \\
(0.181)\end{array}$ & $\begin{array}{l}-0.104 \\
(0.256)\end{array}$ & $\begin{array}{l}-0.099 \\
(0.236)\end{array}$ \\
\hline Financial Income $e_{i, t-2}$ & $\begin{array}{l}-0.014 \\
(0.024)\end{array}$ & $\begin{array}{l}0.162 \\
(0.144)\end{array}$ & $\mid \begin{array}{l}0.004 \\
(0.029)\end{array}$ & $\begin{array}{l}-0.155^{*} \\
(0.081)\end{array}$ & $\begin{array}{l}-0.197^{*} \\
(0.117)\end{array}$ & $\begin{array}{l}-0.165 \\
(0.161)\end{array}$ & \\
\hline Financial Income* & $0.119^{*}$ & 0.278 & $0.176^{*}$ & -0.067 & -0.551 & 0.140 & -0.399 \\
\hline Tradablesi,t & $(0.070)$ & $\mid(0.250)$ & $\mid(0.098)$ & $\mid(0.306)$ & $(0.592)$ & $\mid(0.209)$ & $\mid(0.745)$ \\
\hline Financial Income* & $0.121^{*}$ & -0.021 & $0.122^{*}$ & $0.827^{*}$ & 0.366 & 0.014 & 0.048 \\
\hline Tradables $_{\mathrm{i}, t-1}$ & $(0.067)$ & $(0.205)$ & $\|(0.074)$ & $(0.428)$ & $(0.516)$ & $\|(0.273)$ & (1.068) \\
\hline Financial Income* & 0.026 & -0.222 & 0.019 & 0.234 & -0.006 & 0.154 & \\
\hline Tradables $_{\mathrm{i}, \mathrm{t}-2}$ & $(0.040)$ & $\mid(0.206)$ & $\mid(0.050)$ & $\mid(0.247)$ & $(0.144)$ & $\mid(0.184)$ & \\
\hline Nonfinancial profits $\mathrm{i}_{\mathrm{i}, \mathrm{t}}$ & $\begin{array}{l}0.031 \\
(0.057)\end{array}$ & $\mid \begin{array}{l}0.163^{* *} \\
(0.074)\end{array}$ & \begin{tabular}{|l}
$0.122^{* *}$ \\
$(0.059)$
\end{tabular} & $\begin{array}{l}-0.045 \\
(0.168)\end{array}$ & $\begin{array}{l}-0.027 \\
(0.118)\end{array}$ & $\begin{array}{l}0.135^{* *} \\
(0.061)\end{array}$ & \begin{tabular}{|l}
0.160 \\
$(0.206)$
\end{tabular} \\
\hline Nonfinancial profits $\mathrm{i}_{\mathrm{i}, \mathrm{t}-1}$ & $\begin{array}{l}-0.003 \\
(0.030)\end{array}$ & $\mid \begin{array}{l}0.022 \\
(0.051)\end{array}$ & $\begin{array}{l}0.132^{* * *} \\
(0.040)\end{array}$ & $\mid \begin{array}{l}-0.317^{* * *} \\
(0.102)\end{array}$ & $\begin{array}{l}-0.102 \\
(0.132)\end{array}$ & $\mid \begin{array}{l}0.006 \\
(0.072)\end{array}$ & $\mid \begin{array}{l}-0.152 \\
(0.125)\end{array}$ \\
\hline Nonfinancial profits $\mathrm{i}, \mathrm{t}-2$ & $\begin{array}{l}-0.016 \\
(0.017)\end{array}$ & $\begin{array}{l}0.041 \\
(0.045)\end{array}$ & $\begin{array}{l}0.017 \\
(0.028)\end{array}$ & $\begin{array}{l}-0.122^{*} \\
(0.069)\end{array}$ & $\begin{array}{l}-0.154^{* *} \\
(0.063)\end{array}$ & $\begin{array}{l}-0.052 \\
(0.043)\end{array}$ & \\
\hline Capital Expenditures $\mathrm{i}, \mathrm{t}$ & $\begin{array}{l}-0.224^{* * *} \\
(0.044)\end{array}$ & $\begin{array}{l}-0.174 \\
(0.127)\end{array}$ & $\begin{array}{l}-0.197^{* * *} \\
(0.039)\end{array}$ & $\begin{array}{l}-0.540^{* * *} \\
(0.169)\end{array}$ & $\begin{array}{l}-0.373^{* * *} \\
(0.144)\end{array}$ & $\mid \begin{array}{l}-0.150 \\
(0.125)\end{array}$ & \begin{tabular}{|l}
$-0.262^{*}$ \\
$(0.142)$
\end{tabular} \\
\hline Capital Expenditures $\mathrm{i}_{\mathrm{i}, \mathrm{t}-1}$ & $\begin{array}{l}-0.031 \\
(0.023)\end{array}$ & $\left(\begin{array}{l}-0.004 \\
(0.064)\end{array}\right.$ & $\begin{array}{l}-0.014 \\
(0.031)\end{array}$ & $\begin{array}{l}0.072 \\
(0.047)\end{array}$ & $\begin{array}{l}-0.104 \\
(0.100)\end{array}$ & $\mid \begin{array}{l}-0.073 \\
(0.059)\end{array}$ & $\mid \begin{array}{l}0.038 \\
(0.340)\end{array}$ \\
\hline Capital Expenditures $\mathrm{i}_{\mathrm{i}, \mathrm{t}-2}$ & $\begin{array}{l}0.049^{* *} \\
(0.021)\end{array}$ & $\mid \begin{array}{l}0.081 \\
(0.053)\end{array}$ & $\begin{array}{l}0.043 \\
(0.032)\end{array}$ & $\begin{array}{l}0.015 \\
(0.043)\end{array}$ & $\begin{array}{l}-0.009 \\
(0.078)\end{array}$ & $\mid \begin{array}{l}0.135^{* *} \\
(0.056)\end{array}$ & \\
\hline Payouts $_{\mathrm{i}, \mathrm{t}}$ & $\begin{array}{l}0.056 \\
(0.078)\end{array}$ & $\begin{array}{l}-0.008 \\
(0.179)\end{array}$ & $\mid \begin{array}{l}-0.149 \\
(0.106)\end{array}$ & $\begin{array}{l}0.164 \\
(0.139)\end{array}$ & $\begin{array}{l}0.259 \\
(0.192)\end{array}$ & $\mid \begin{array}{l}-0.127 \\
(0.106)\end{array}$ & $\mid \begin{array}{l}0.431 \\
(1.605)\end{array}$ \\
\hline Payoutsi,t-1 $_{1}$ & $\begin{array}{l}0.066 \\
(0.042)\end{array}$ & $\begin{array}{l}-0.052 \\
(0.201)\end{array}$ & $\mid \begin{array}{l}-0.053 \\
(0.092)\end{array}$ & $\begin{array}{l}0.009 \\
(0.076)\end{array}$ & $\begin{array}{l}0.058 \\
(0.227)\end{array}$ & $\mid \begin{array}{l}0.165^{* *} \\
(0.068)\end{array}$ & $\begin{array}{l}0.100 \\
(0.552)\end{array}$ \\
\hline Payoutsi,t-2 & $\begin{array}{l}0.002 \\
(0.034)\end{array}$ & $\begin{array}{l}-0.056 \\
(0.094)\end{array}$ & $\begin{array}{l}0.010 \\
(0.059)\end{array}$ & $\begin{array}{l}-0.049 \\
(0.052)\end{array}$ & $\begin{array}{l}0.064 \\
(0.141)\end{array}$ & $\begin{array}{l}0.137^{*} \\
(0.080)\end{array}$ & \\
\hline Leverage $_{\mathrm{i}, \mathrm{t}}$ & $\begin{array}{l}-0.042^{* * *} \\
(0.016)\end{array}$ & $\begin{array}{l}0.025 \\
(0.046)\end{array}$ & $\begin{array}{l}-0.004 \\
(0.015)\end{array}$ & $\begin{array}{l}-0.106 \\
(0.114)\end{array}$ & $\begin{array}{l}-0.041 \\
(0.083)\end{array}$ & $\mid \begin{array}{l}-0.058 \\
(0.051)\end{array}$ & $\mid \begin{array}{l}-0.068 \\
(0.071)\end{array}$ \\
\hline Leverage $_{\mathrm{i}, \mathrm{t}-1}$ & $\begin{array}{l}0.107^{*} \\
(0.063)\end{array}$ & $\begin{array}{l}0.016 \\
(0.038)\end{array}$ & $\mid \begin{array}{l}-0.021 \\
(0.047)\end{array}$ & $\mid \begin{array}{l}-0.120 \\
(0.201)\end{array}$ & $\begin{array}{l}0.180^{* * *} \\
(0.065)\end{array}$ & \begin{tabular}{l|l}
0.015 \\
$(0.048)$
\end{tabular} & $\mid \begin{array}{l}-0.031 \\
(0.132)\end{array}$ \\
\hline Leverage $_{\mathrm{i}, \mathrm{t}-2}$ & $\begin{array}{l}-0.017 * * \\
(0.007)\end{array}$ & $\mid \begin{array}{l}-0.034 \\
(0.024)\end{array}$ & $\begin{array}{l}-0.015^{* *} \\
(0.007)\end{array}$ & $\mid \begin{array}{l}-0.004 \\
(0.032)\end{array}$ & $\begin{array}{l}-0.053^{*} \\
(0.028)\end{array}$ & $\begin{array}{l}0.025 \\
(0.026)\end{array}$ & \\
\hline $\log (\text { Assets })_{\mathrm{I}, \mathrm{t}}$ & $\begin{array}{l}0.037^{* * *} \\
(0.011)\end{array}$ & $\mid \begin{array}{l}0.012 \\
(0.014)\end{array}$ & $\begin{array}{l}0.015 \\
(0.014)\end{array}$ & $\mid \begin{array}{l}0.106 \\
(0.072)\end{array}$ & $\begin{array}{l}0.079^{*} \\
(0.040)\end{array}$ & $\mid \begin{array}{l}0.030 \\
(0.036)\end{array}$ & $\mid \begin{array}{l}0.034 \\
(0.037)\end{array}$ \\
\hline $\log (\text { Assets })_{\mathrm{I}, \mathrm{t}-1}$ & $\begin{array}{l}-0.065^{* * *} \\
(0.020)\end{array}$ & $\begin{array}{l}-0.027 \\
(0.025)\end{array}$ & $\mid \begin{array}{l}-0.017 \\
(0.016)\end{array}$ & $\begin{array}{l}-0.160 \\
(0.118)\end{array}$ & $\begin{array}{l}-0.142^{* *} \\
(0.060)\end{array}$ & $\mid \begin{array}{l}-0.043 \\
(0.068)\end{array}$ & $\begin{array}{l}-0.005 \\
(0.029)\end{array}$ \\
\hline $\log (\text { Assets })_{\mathrm{I}, \mathrm{t}-2}$ & $\begin{array}{l}0.003 \\
(0.004)\end{array}$ & $\begin{array}{l}0.007 \\
(0.016)\end{array}$ & $\mid \begin{array}{l}0.002 \\
(0.009)\end{array}$ & $\begin{array}{l}-0.014 \\
(0.010)\end{array}$ & $\begin{array}{l}0.001 \\
(0.012)\end{array}$ & $\begin{array}{l}-0.003 \\
(0.010)\end{array}$ & \\
\hline Dummy_Tradables $_{\mathrm{j}, \mathrm{t}}$ & $\begin{array}{l}-0.020^{* *} \\
(0.008)\end{array}$ & $\begin{array}{l}-0.012 \\
(0.018)\end{array}$ & $\left(\begin{array}{l}0.002 \\
(0.010)\end{array}\right.$ & $\begin{array}{l}-0.039 \\
(0.026)\end{array}$ & $\begin{array}{l}-0.007 \\
(0.025)\end{array}$ & $\mid \begin{array}{l}-0.011 \\
(0.032)\end{array}$ & \begin{tabular}{|l}
-0.005 \\
$(0.036)$
\end{tabular} \\
\hline N. obs & 11,734 & 1,076 & 4,672 & 2,441 & 1,744 & 1,306 & 532 \\
\hline $\mathrm{N}$. firms & 883 & 75 & 374 & 173 & 130 & 88 & 43 \\
\hline Instruments & 63 & 61 & 63 & 63 & 63 & 63 & 53 \\
\hline $\operatorname{ar} 1 p$ & 0.000 & 0.000 & 0.000 & 0.000 & 0.000 & 0.000 & 0.003 \\
\hline $\operatorname{ar} 2 p$ & 0.636 & 0.653 & 0.525 & 0.640 & 0.206 & 0.870 & 0.468 \\
\hline hansen & 0.694 & 0.605 & 0.362 & 0.804 & 0.662 & 0.790 & 0.998 \\
\hline
\end{tabular}


Table 4. Estimation results based on equation (1). Period: 1997-2007.

\begin{tabular}{|c|c|c|c|c|c|c|c|}
\hline $\begin{array}{c}\text { Dependent } \\
\text { variable:Cash\&St.Inv } \mathrm{i}, \mathrm{t}\end{array}$ & $\begin{array}{c}\text { All } \\
\text { countries }\end{array}$ & Argentina & Brazil & Chile & Mexico & Peru & Colombia \\
\hline Cash\&St.Invi,t-1 & $\begin{array}{l}0.655^{* * *} \\
(0.049)\end{array}$ & $\begin{array}{l}0.466^{* * *} \\
(0.149)\end{array}$ & \begin{tabular}{|l|}
$0.654^{* * *}$ \\
$(0.072)$
\end{tabular} & $\begin{array}{l}0.348^{* * *} \\
(0.118)\end{array}$ & \begin{tabular}{|l}
$0.737^{* * *}$ \\
$(0.123)$
\end{tabular} & $\begin{array}{l}0.526^{* * *} \\
(0.188)\end{array}$ & \begin{tabular}{|l}
$0.374^{* *}$ \\
$(0.168)$
\end{tabular} \\
\hline Cash\&St.Invi,t-2 & $\begin{array}{l}0.122^{* *} \\
(0.049)\end{array}$ & $\begin{array}{l}-0.209^{* *} \\
(0.095)\end{array}$ & $\begin{array}{l}0.188^{* * *} \\
(0.070)\end{array}$ & $\begin{array}{l}-0.003 \\
(0.090)\end{array}$ & $\begin{array}{l}0.094 \\
(0.119)\end{array}$ & $\begin{array}{l}-0.015 \\
(0.174)\end{array}$ & $\begin{array}{l}-0.584 \\
(0.741)\end{array}$ \\
\hline Cash\&St.Invi,t-3 & $\begin{array}{l}-0.004 \\
(0.033)\end{array}$ & $\begin{array}{l}-0.111^{*} \\
(0.061)\end{array}$ & $\begin{array}{l}-0.006 \\
(0.039)\end{array}$ & $\begin{array}{l}-0.056 \\
(0.064)\end{array}$ & $\begin{array}{l}0.028 \\
(0.104)\end{array}$ & $\begin{array}{l}0.150 \\
(0.137)\end{array}$ & \\
\hline Financial Income $e_{i, t}$ & $\begin{array}{l}0.036 \\
(0.046)\end{array}$ & $\begin{array}{l}-0.036 \\
(0.133)\end{array}$ & $\begin{array}{l}0.026 \\
(0.062)\end{array}$ & $\begin{array}{l}-0.091 \\
(0.110)\end{array}$ & $\mid \begin{array}{l}0.030 \\
(0.264)\end{array}$ & $\begin{array}{l}0.272 \\
(0.325)\end{array}$ & $\begin{array}{l}0.013 \\
(0.473)\end{array}$ \\
\hline Financial Income $e_{i, t-1}$ & $\begin{array}{l}-0.021 \\
(0.040)\end{array}$ & $\begin{array}{l}0.031 \\
(0.070)\end{array}$ & $\begin{array}{l}-0.016 \\
(0.058)\end{array}$ & $\begin{array}{l}0.265^{* *} \\
(0.131)\end{array}$ & $\begin{array}{l}-0.073 \\
(0.143)\end{array}$ & $\begin{array}{l}0.058 \\
(0.167)\end{array}$ & $\begin{array}{l}-0.301 \\
(0.526)\end{array}$ \\
\hline Financial Income $e_{i, t-2}$ & $\begin{array}{l}-0.018 \\
(0.024)\end{array}$ & $\begin{array}{l}-0.096 \\
(0.065)\end{array}$ & $\begin{array}{l}-0.019 \\
(0.035)\end{array}$ & $\begin{array}{l}-0.132^{* *} \\
(0.058)\end{array}$ & $\begin{array}{l}-0.072 \\
(0.079)\end{array}$ & $\begin{array}{l}-0.008 \\
(0.148)\end{array}$ & \\
\hline Nonfinancial profits $\mathrm{i}_{\mathrm{i}, \mathrm{t}}$ & $\begin{array}{l}0.008 \\
(0.057)\end{array}$ & $\begin{array}{l}-0.207 \\
(0.135)\end{array}$ & $\begin{array}{l}0.050 \\
(0.060)\end{array}$ & $\begin{array}{l}0.115 \\
(0.091)\end{array}$ & $\begin{array}{l}0.216^{*} \\
(0.119)\end{array}$ & $\begin{array}{l}0.344^{* *} \\
(0.151)\end{array}$ & $\begin{array}{l}0.580^{* * *} \\
(0.208)\end{array}$ \\
\hline Nonfinancial profitsi,t-1 & $\begin{array}{l}0.008 \\
(0.044)\end{array}$ & $\begin{array}{l}-0.035 \\
(0.083)\end{array}$ & $\begin{array}{l}0.133^{* * *} \\
(0.051)\end{array}$ & $\begin{array}{l}0.169 \\
(0.163)\end{array}$ & $\begin{array}{l}0.062 \\
(0.126)\end{array}$ & $\begin{array}{l}0.207 \\
(0.167)\end{array}$ & $\begin{array}{l}-0.458 \\
(0.595)\end{array}$ \\
\hline Nonfinancial profits $\mathrm{i}_{\mathrm{i}, \mathrm{t}-2}$ & $\begin{array}{l}-0.037 \\
(0.026)\end{array}$ & $\begin{array}{l}-0.101 \\
(0.077)\end{array}$ & $\begin{array}{l}-0.001 \\
(0.036)\end{array}$ & $\begin{array}{l}0.017 \\
(0.058)\end{array}$ & $\begin{array}{l}-0.040 \\
(0.075)\end{array}$ & $\begin{array}{l}-0.013 \\
(0.091)\end{array}$ & \\
\hline Capital Expendituresi,t & $\begin{array}{l}-0.256^{* * *} \\
(0.051)\end{array}$ & $\begin{array}{l}-0.006 \\
(0.178)\end{array}$ & $\begin{array}{l}-0.209^{* * *} \\
(0.068)\end{array}$ & $\begin{array}{l}0.164 \\
(0.224)\end{array}$ & $\begin{array}{l}-0.171 \\
(0.140)\end{array}$ & $\begin{array}{l}-0.218 \\
(0.203)\end{array}$ & $\begin{array}{l}0.631 \\
(0.915)\end{array}$ \\
\hline Capital Expendituresi,t-1 & $\begin{array}{l}-0.071^{* *} \\
(0.034)\end{array}$ & $\begin{array}{l}-0.068 \\
(0.161)\end{array}$ & $\begin{array}{l}-0.063 \\
(0.048)\end{array}$ & $\begin{array}{l}-0.025 \\
(0.051)\end{array}$ & $\mid \begin{array}{l}-0.006 \\
(0.107)\end{array}$ & $\begin{array}{l}0.070 \\
(0.134)\end{array}$ & $\begin{array}{l}-0.608 \\
(0.589)\end{array}$ \\
\hline Capital Expendituresi,t-2 & $\begin{array}{l}0.009 \\
(0.026)\end{array}$ & $\begin{array}{l}0.045 \\
(0.083)\end{array}$ & $\begin{array}{l}0.053 \\
(0.038)\end{array}$ & $\begin{array}{l}-0.027 \\
(0.047)\end{array}$ & $\mid \begin{array}{l}0.095 \\
(0.088)\end{array}$ & $\begin{array}{l}0.115 \\
(0.108)\end{array}$ & \\
\hline Payouts $_{\mathrm{i}, \mathrm{t}}$ & $\begin{array}{l}0.063 \\
(0.088)\end{array}$ & $\begin{array}{l}0.273 \\
(0.298)\end{array}$ & $\begin{array}{l}0.082 \\
(0.208)\end{array}$ & $\begin{array}{l}-0.142 \\
(0.143)\end{array}$ & $\mid \begin{array}{l}-0.024 \\
(0.274)\end{array}$ & $\begin{array}{l}-0.230 \\
(0.246)\end{array}$ & $\begin{array}{l}-0.434 \\
(1.582)\end{array}$ \\
\hline Payoutsi,t-1 & $\begin{array}{l}0.077 \\
(0.085)\end{array}$ & $\begin{array}{l}0.082 \\
(0.143)\end{array}$ & $\begin{array}{l}0.172 \\
(0.197)\end{array}$ & $\begin{array}{l}0.061 \\
(0.070)\end{array}$ & $\mid \begin{array}{l}0.269 \\
(0.345)\end{array}$ & $\begin{array}{l}-0.027 \\
(0.193)\end{array}$ & $\begin{array}{l}-0.160 \\
(1.555)\end{array}$ \\
\hline Payoutsi,t-2 & $\begin{array}{l}0.109 * \\
(0.062)\end{array}$ & $\begin{array}{l}-0.028 \\
(0.145)\end{array}$ & $\begin{array}{l}0.143 \\
(0.156)\end{array}$ & $\begin{array}{l}-0.024 \\
(0.064)\end{array}$ & $\begin{array}{l}0.403^{*} \\
(0.216)\end{array}$ & $\begin{array}{l}-0.108 \\
(0.124)\end{array}$ & \\
\hline Leverage $_{\mathrm{i}, \mathrm{t}}$ & $\begin{array}{l}-0.031^{* * *} \\
(0.011)\end{array}$ & $\begin{array}{l}-0.078^{* *} \\
(0.035)\end{array}$ & $\begin{array}{l}-0.026^{* *} \\
(0.013)\end{array}$ & $\begin{array}{l}-0.072 \\
(0.046)\end{array}$ & $\mid \begin{array}{l}-0.104 \\
(0.083)\end{array}$ & $\begin{array}{l}0.125 \\
(0.137)\end{array}$ & $\begin{array}{l}-0.128 \\
(0.329)\end{array}$ \\
\hline Leverage $_{\mathrm{i}, \mathrm{t}-1}$ & $\begin{array}{l}0.038 \\
(0.050)\end{array}$ & $\begin{array}{l}0.014 \\
(0.044)\end{array}$ & $\begin{array}{l}0.010 \\
(0.039)\end{array}$ & $\begin{array}{l}-0.063 \\
(0.073)\end{array}$ & $\mid \begin{array}{l}0.078 \\
(0.056)\end{array}$ & $\begin{array}{l}-0.132 \\
(0.103)\end{array}$ & $\begin{array}{l}0.069 \\
(0.431)\end{array}$ \\
\hline Leverage $\mathrm{i}_{\mathrm{i}-\mathrm{t}}$ & $\begin{array}{l}-0.009 \\
(0.009)\end{array}$ & $\begin{array}{l}-0.031 \\
(0.044)\end{array}$ & $\begin{array}{l}-0.003 \\
(0.011)\end{array}$ & $\begin{array}{l}0.007 \\
(0.022)\end{array}$ & $\begin{array}{l}-0.021 \\
(0.041)\end{array}$ & $\begin{array}{l}-0.013 \\
(0.044)\end{array}$ & \\
\hline $\log (\text { Assets })_{\mathrm{I}, \mathrm{t}}$ & $\begin{array}{l}0.044^{* * *} \\
(0.013)\end{array}$ & $\begin{array}{l}0.087 \\
(0.069)\end{array}$ & $\begin{array}{l}0.018 \\
(0.018)\end{array}$ & $\begin{array}{l}-0.015 \\
(0.050)\end{array}$ & $\begin{array}{l}-0.011 \\
(0.048)\end{array}$ & $\begin{array}{l}0.016 \\
(0.081)\end{array}$ & $\begin{array}{l}0.076 \\
(0.071)\end{array}$ \\
\hline $\log (\text { Assets })_{\mathrm{I}, \mathrm{t}-1}$ & $\begin{array}{l}-0.057^{* * *} \\
(0.017)\end{array}$ & $\begin{array}{l}-0.116 \\
(0.088)\end{array}$ & $\begin{array}{l}-0.026 \\
(0.024)\end{array}$ & $\begin{array}{l}0.097 \\
(0.073)\end{array}$ & $\begin{array}{l}0.013 \\
(0.061)\end{array}$ & $\begin{array}{l}-0.031 \\
(0.090)\end{array}$ & $\begin{array}{l}-0.073 \\
(0.062)\end{array}$ \\
\hline $\log (\text { Assets) })_{\mathrm{I}, \mathrm{t}-2}$ & $\begin{array}{l}-0.003 \\
(0.005)\end{array}$ & $\begin{array}{l}0.023 \\
(0.034)\end{array}$ & $\begin{array}{l}-0.011 \\
(0.008)\end{array}$ & $\begin{array}{l}-0.020^{* *} \\
(0.008)\end{array}$ & $\begin{array}{l}-0.003 \\
(0.013)\end{array}$ & $\begin{array}{l}0.038 \\
(0.027)\end{array}$ & \\
\hline N. obs & 4,959 & 433 & 2,091 & 1,033 & 750 & 474 & 198 \\
\hline N. firms & 720 & 64 & 313 & 137 & 106 & 73 & 27 \\
\hline Instruments & 58 & 52 & 53 & 53 & 53 & 53 & 39 \\
\hline $\operatorname{ar} 1 p$ & 0.000 & 0.001 & 0.000 & 0.000 & 0.049 & 0.023 & 0.332 \\
\hline $\operatorname{ar} 2 \mathrm{p}$ & 0.839 & 0.680 & 0.774 & 0.949 & 0.183 & 0.824 & 0.405 \\
\hline hansen & 0.181 & 0.263 & 0.340 & 0.355 & 0.635 & 0.493 & 1.000 \\
\hline
\end{tabular}

Estimations are all obtained by the Arellano-Bond two-step difference GMM. All instruments include up to four year lags. ar1p and ar2p are Arellano-Bond test of first order and second order autocorrelation in the errors. hansen is the HansenSargan test of overidentifying restrictions for all instruments. Year and sectoral dummies included in all cases. Country dummies included for the whole sample estimation. P-values are reported for all tests. * indicates significance at $10 \%,{ }^{* *}$ significance at $5 \%$ and ${ }^{* * *}$ significance at $1 \%$. 
Table 5. Estimation results based on equation (1). Period: 2008-2018.

\begin{tabular}{|c|c|c|c|c|c|c|c|}
\hline $\begin{array}{c}\text { Dependent } \\
\text { variable:Cash\&St.Inv } \mathrm{i}, \mathrm{t}\end{array}$ & $\begin{array}{c}\text { All } \\
\text { countries }\end{array}$ & Argentina & Brazil & Chile & Mexico & Peru & Colombia \\
\hline Cash\&St.Inv $v_{i, t-1}$ & $\begin{array}{l}0.634^{* * *} \\
(0.031)\end{array}$ & \begin{tabular}{|l|}
$0.630^{* * *}$ \\
$(0.104)$
\end{tabular} & $\begin{array}{l}0.598^{* * *} \\
(0.055)\end{array}$ & $\begin{array}{l}0.519^{* * *} \\
(0.084)\end{array}$ & \begin{tabular}{|l|}
$0.594^{* * *}$ \\
$(0.149)$
\end{tabular} & \begin{tabular}{|l}
$0.547^{* * *}$ \\
$(0.092)$
\end{tabular} & \begin{tabular}{|l|}
$0.801^{* * *}$ \\
$(0.157)$
\end{tabular} \\
\hline Cash\&St.Invi,t-2 & $\begin{array}{l}0.055^{* *} \\
(0.024)\end{array}$ & $\begin{array}{l}0.058 \\
(0.132)\end{array}$ & $\begin{array}{l}0.043 \\
(0.036)\end{array}$ & $\begin{array}{l}-0.008 \\
(0.047)\end{array}$ & $\begin{array}{l}0.000 \\
(0.111)\end{array}$ & $\begin{array}{l}0.109 \\
(0.074)\end{array}$ & $\begin{array}{l}-0.192 \\
(0.161)\end{array}$ \\
\hline Cash\&St.Invi,t-3 & $\begin{array}{l}0.016 \\
(0.020)\end{array}$ & $\begin{array}{l}0.009 \\
(0.060)\end{array}$ & $\begin{array}{l}0.035 \\
(0.032)\end{array}$ & $\begin{array}{l}0.004 \\
(0.039)\end{array}$ & $\begin{array}{l}-0.022 \\
(0.059)\end{array}$ & $\begin{array}{l}-0.125^{*} \\
(0.065)\end{array}$ & \\
\hline Financial Income $e_{i, t}$ & $\begin{array}{l}0.284^{* * *} \\
(0.059)\end{array}$ & $\begin{array}{l}0.013 \\
(0.288)\end{array}$ & $\begin{array}{l}0.333^{* * *} \\
(0.078)\end{array}$ & $\begin{array}{l}0.168 \\
(0.133)\end{array}$ & $\begin{array}{l}-0.828 \\
(1.082)\end{array}$ & $\mid \begin{array}{l}0.103 \\
(0.095)\end{array}$ & $\begin{array}{l}0.137 \\
(0.101)\end{array}$ \\
\hline Financial Income $e_{i, t-1}$ & $\begin{array}{l}-0.056 \\
(0.066)\end{array}$ & $\begin{array}{l}0.183 \\
(0.298)\end{array}$ & $\begin{array}{l}-0.045 \\
(0.097)\end{array}$ & $\begin{array}{l}0.234 \\
(0.364)\end{array}$ & $\begin{array}{l}-0.817 \\
(0.885)\end{array}$ & $\begin{array}{l}-0.157 \\
(0.112)\end{array}$ & $\begin{array}{l}-0.050 \\
(0.079)\end{array}$ \\
\hline Financial Income $e_{i, t-2}$ & $\begin{array}{l}0.016 \\
(0.043)\end{array}$ & $\begin{array}{l}0.283 \\
(0.221)\end{array}$ & $\begin{array}{l}0.015 \\
(0.054)\end{array}$ & $\begin{array}{l}0.020 \\
(0.282)\end{array}$ & $\begin{array}{l}0.026 \\
(0.184)\end{array}$ & $\mid \begin{array}{l}0.003 \\
(0.105)\end{array}$ & \\
\hline Nonfinancial profits $\mathrm{i}, \mathrm{t}$ & $\begin{array}{l}0.147^{* * *} \\
(0.044)\end{array}$ & $\begin{array}{l}0.273^{* * *} \\
(0.095)\end{array}$ & $\begin{array}{l}0.097^{*} \\
(0.050)\end{array}$ & $\begin{array}{l}0.266^{* *} \\
(0.129)\end{array}$ & $\begin{array}{l}-0.328 \\
(0.235)\end{array}$ & $\begin{array}{l}0.179^{* *} \\
(0.074)\end{array}$ & $\begin{array}{l}0.033 \\
(0.186)\end{array}$ \\
\hline Nonfinancial profits $s_{i, t-1}$ & $\begin{array}{l}0.021 \\
(0.029)\end{array}$ & $\begin{array}{l}0.059 \\
(0.079)\end{array}$ & $\begin{array}{l}0.055 \\
(0.043)\end{array}$ & $\begin{array}{l}-0.140^{*} \\
(0.083)\end{array}$ & $\begin{array}{l}-0.037 \\
(0.198)\end{array}$ & $\mid \begin{array}{l}0.082 \\
(0.081)\end{array}$ & $\begin{array}{l}0.020 \\
(0.190)\end{array}$ \\
\hline Nonfinancial profitsi,t-2 & $\begin{array}{l}-0.004 \\
(0.023)\end{array}$ & $\begin{array}{l}0.125^{* *} \\
(0.053)\end{array}$ & $\begin{array}{l}0.014 \\
(0.033)\end{array}$ & $\begin{array}{l}-0.031 \\
(0.043)\end{array}$ & $\begin{array}{l}-0.100 \\
(0.079)\end{array}$ & $\begin{array}{l}0.020 \\
(0.057)\end{array}$ & \\
\hline Capital Expenditures $s_{i, t}$ & $\begin{array}{l}-0.260^{* * *} \\
(0.061)\end{array}$ & $\begin{array}{l}-0.414^{*} \\
(0.214)\end{array}$ & $\begin{array}{l}-0.306^{* * *} \\
(0.087)\end{array}$ & $\begin{array}{l}-0.139 \\
(0.139)\end{array}$ & $\begin{array}{l}-0.292 \\
(0.179)\end{array}$ & $\mid \begin{array}{l}-0.054 \\
(0.135)\end{array}$ & $\begin{array}{l}-0.158 \\
(0.151)\end{array}$ \\
\hline Capital Expenditures $\mathrm{s}_{\mathrm{i}, \mathrm{t}-1}$ & $\begin{array}{l}0.017 \\
(0.030)\end{array}$ & $\begin{array}{l}0.065 \\
(0.111)\end{array}$ & $\begin{array}{l}0.005 \\
(0.046)\end{array}$ & $\begin{array}{l}0.082 \\
(0.070)\end{array}$ & $\begin{array}{l}-0.116 \\
(0.148)\end{array}$ & $\mid \begin{array}{l}-0.022 \\
(0.059)\end{array}$ & $\begin{array}{l}0.009 \\
(0.145)\end{array}$ \\
\hline Capital Expenditures $\mathrm{s}_{\mathrm{i}, \mathrm{-}-2}$ & $\begin{array}{l}0.059 * * \\
(0.029)\end{array}$ & $\begin{array}{l}0.044 \\
(0.083)\end{array}$ & $\begin{array}{l}0.015 \\
(0.049)\end{array}$ & $\begin{array}{l}0.043 \\
(0.051)\end{array}$ & $\begin{array}{l}0.024 \\
(0.078)\end{array}$ & \begin{tabular}{|c}
$0.159^{* *}$ \\
$(0.071)$
\end{tabular} & \\
\hline Payouts $_{\mathrm{i}, \mathrm{t}}$ & $\begin{array}{l}-0.065 \\
(0.069)\end{array}$ & $\begin{array}{l}-0.232 \\
(0.271)\end{array}$ & $\begin{array}{l}-0.122 \\
(0.138)\end{array}$ & $\begin{array}{l}-0.073 \\
(0.121)\end{array}$ & $\begin{array}{l}0.174 \\
(0.232)\end{array}$ & $\begin{array}{l}-0.223 \\
(0.160)\end{array}$ & $\begin{array}{l}-0.100 \\
(0.565)\end{array}$ \\
\hline Payoutsi,t-1 & $\begin{array}{l}0.045 \\
(0.050)\end{array}$ & $\begin{array}{l}-0.100 \\
(0.265)\end{array}$ & $\begin{array}{l}-0.042 \\
(0.090)\end{array}$ & $\begin{array}{l}0.046 \\
(0.064)\end{array}$ & $\begin{array}{l}0.088 \\
(0.201)\end{array}$ & $\begin{array}{l}0.209^{* *} \\
(0.086)\end{array}$ & $\begin{array}{l}-0.019 \\
(0.379)\end{array}$ \\
\hline Payoutsi,t-2 & $\begin{array}{l}-0.058 \\
(0.041)\end{array}$ & $\begin{array}{l}-0.099 \\
(0.120)\end{array}$ & $\begin{array}{l}-0.006 \\
(0.063)\end{array}$ & $\begin{array}{l}-0.214^{* * *} \\
(0.063)\end{array}$ & $\begin{array}{l}-0.031 \\
(0.132)\end{array}$ & $\mid \begin{array}{l}0.176^{* *} \\
(0.088)\end{array}$ & \\
\hline Leverage $_{\mathrm{i}, \mathrm{t}}$ & $\begin{array}{l}-0.024 \\
(0.018)\end{array}$ & $\begin{array}{l}0.017 \\
(0.075)\end{array}$ & $\begin{array}{l}-0.021 \\
(0.022)\end{array}$ & $\begin{array}{l}0.023 \\
(0.065)\end{array}$ & $\begin{array}{l}-0.101 \\
(0.117)\end{array}$ & $\mid \begin{array}{l}-0.083 \\
(0.071)\end{array}$ & $\begin{array}{l}-0.071 \\
(0.129)\end{array}$ \\
\hline Leverage $\mathrm{i}_{\mathrm{i}-\mathrm{1}}$ & $\begin{array}{l}0.051^{*} \\
(0.026)\end{array}$ & $\begin{array}{l}0.036 \\
(0.068)\end{array}$ & $\begin{array}{l}-0.003 \\
(0.025)\end{array}$ & $\begin{array}{l}-0.075 \\
(0.150)\end{array}$ & $\begin{array}{l}0.210^{* *} \\
(0.105)\end{array}$ & $\begin{array}{l}0.017 \\
(0.080)\end{array}$ & $\begin{array}{l}-0.049 \\
(0.102)\end{array}$ \\
\hline Leverage $_{\mathrm{i}, \mathrm{t}-\mathrm{2}}$ & $\begin{array}{l}-0.020^{* *} \\
(0.008)\end{array}$ & $\begin{array}{l}-0.018 \\
(0.037)\end{array}$ & $\begin{array}{l}-0.019 * * \\
(0.010)\end{array}$ & $\begin{array}{l}0.003 \\
(0.038)\end{array}$ & $\begin{array}{l}-0.031 \\
(0.040)\end{array}$ & $\mid \begin{array}{l}0.042 \\
(0.036)\end{array}$ & \\
\hline $\log (\text { Assets })_{\mathrm{I}, \mathrm{t}}$ & $\begin{array}{l}0.015 \\
(0.009)\end{array}$ & $\begin{array}{l}-0.013 \\
(0.028)\end{array}$ & $\begin{array}{l}0.023 \\
(0.015)\end{array}$ & $\begin{array}{l}-0.002 \\
(0.028)\end{array}$ & $\begin{array}{l}0.084 \\
(0.059)\end{array}$ & $\begin{array}{l}-0.033^{*} \\
(0.019)\end{array}$ & $\begin{array}{l}0.057 \\
(0.036)\end{array}$ \\
\hline $\log (\text { Assets })_{\mathrm{l}, \mathrm{t}-1}$ & $\begin{array}{l}-0.034 \\
(0.024)\end{array}$ & $\begin{array}{l}-0.035 \\
(0.053)\end{array}$ & $\begin{array}{l}-0.069^{*} \\
(0.037)\end{array}$ & $\begin{array}{l}0.009 \\
(0.044)\end{array}$ & $\begin{array}{l}-0.180^{* *} \\
(0.080)\end{array}$ & \begin{tabular}{|l}
0.045 \\
$(0.035)$
\end{tabular} & $\begin{array}{l}0.003 \\
(0.060)\end{array}$ \\
\hline $\log (\text { Assets })_{\mathrm{I}, \mathrm{t}-2}$ & $\begin{array}{l}0.004 \\
(0.006) \\
\end{array}$ & $\begin{array}{l}0.007 \\
(0.018) \\
\end{array}$ & $\begin{array}{l}0.020 \\
(0.014) \\
\end{array}$ & $\begin{array}{l}-0.006 \\
(0.011)\end{array}$ & $\begin{array}{l}-0.012 \\
(0.020)\end{array}$ & $\begin{array}{l}-0.013 \\
(0.012)\end{array}$ & \\
\hline N. obs & 6,775 & 643 & 2,581 & 1,408 & 994 & 832 & 334 \\
\hline N. firms & 755 & 67 & 297 & 161 & 109 & 86 & 35 \\
\hline Instruments & 58 & 53 & 53 & 53 & 53 & 53 & 37 \\
\hline $\operatorname{ar} 1 \mathrm{p}$ & 0.000 & 0.000 & 0.000 & 0.000 & 0.000 & 0.000 & 0.015 \\
\hline $\operatorname{ar} 2 p$ & 0.725 & 0.698 & 0.659 & 0.745 & 0.325 & 0.220 & 0.429 \\
\hline hansen & 0.410 & 0.875 & 0.438 & 0.744 & 0.286 & 0.912 & 0.912 \\
\hline
\end{tabular}

Estimations are all obtained by the Arellano-Bond two-step difference GMM. All instruments include up to four year lags. $\operatorname{ar} 1 \mathrm{p}$ and ar2p are Arellano-Bond test of first order and second order autocorrelation in the errors. hansen is the HansenSargan test of overidentifying restrictions for all instruments. Year and sectoral dummies included in all cases. Country dummies included for the whole sample estimation. P-values are reported for all tests. ${ }^{*}$ indicates significance at $10 \%,{ }^{* *}$ significance at $5 \%$ and ${ }^{* * *}$ significance at $1 \%$.

\section{b. Robustness checks and further analysis}

To evaluate how robust our results are, we will carry different exercises. For reasons of space, we only present the results for our variables of interest. Full tables can be found in the Appendix. 
First, rather than estimating the effect of financial income on cash holdings we will take a far-reaching variable: nonoperating income (Compustat Data Item 61). This variable is broader than financial income including any income (or expense as well) that results from secondary or nonoperating business-related activities (i.e., excluding those considered part of the normal operations of the business). Therefore, it may be able to capture further effects related to financial activities such as capital gains and foreign exchange gains. We repeat the exercise of dividing the sample in two periods (Table 6 and 7) and find again positive and statistically significant results for the second for Argentina and Brazil. ${ }^{8}$

Table 6. Estimation results for nonoperating income instead of financial income based on equation (1). Period: 1997-2007.

\begin{tabular}{|c|c|c|c|c|c|c|c|}
\hline $\begin{array}{c}\text { Dependent } \\
\text { variable:Cash\&St.Invi,t }\end{array}$ & $\begin{array}{c}\text { All } \\
\text { countries }\end{array}$ & Argentina & Brazil & Chile & Mexico & Peru & Colombia \\
\hline Non-operating Income $e_{i, t}$ & $\begin{array}{l}-0.013 \\
(0.010)\end{array}$ & \begin{tabular}{|l|}
-0.025 \\
$(0.021)$
\end{tabular} & $\begin{array}{l}-0.019 \\
(0.015)\end{array}$ & $\begin{array}{l}0.011 \\
(0.019)\end{array}$ & $\begin{array}{l}0.037 \\
(0.030)\end{array}$ & \begin{tabular}{|l|}
0.077 \\
$(0.049)$
\end{tabular} & $\begin{array}{l}0.012 \\
(0.045)\end{array}$ \\
\hline Non-operating Income $e_{i, t-1}$ & $\begin{array}{l}-0.007 \\
(0.006)\end{array}$ & $\begin{array}{l}-0.031 \\
(0.020)\end{array}$ & $\begin{array}{l}-0.015^{*} \\
(0.009)\end{array}$ & $\begin{array}{l}0.013 \\
(0.010)\end{array}$ & $\begin{array}{l}0.016 \\
(0.040)\end{array}$ & $\begin{array}{l}-0.009 \\
(0.028)\end{array}$ & $\begin{array}{l}-0.011 \\
(0.029)\end{array}$ \\
\hline Non-operating Income $\mathrm{i}_{\mathrm{i}, \mathrm{t}}$ & $\begin{array}{l}0.000 \\
(0.005)\end{array}$ & $\begin{array}{l}-0.012 \\
(0.013)\end{array}$ & $\begin{array}{l}-0.004 \\
(0.006)\end{array}$ & $\begin{array}{l}0.006 \\
(0.006)\end{array}$ & $\begin{array}{l}0.012 \\
(0.020)\end{array}$ & $\begin{array}{l}-0.014 \\
(0.029)\end{array}$ & \\
\hline N. obs & 4,959 & 433 & 2,091 & 1,033 & 750 & 474 & 198 \\
\hline N. firms & 720 & 64 & 313 & 137 & 106 & 73 & 27 \\
\hline Instruments & 58 & 52 & 53 & 53 & 53 & 53 & 39 \\
\hline $\operatorname{ar} 1 p$ & 0.000 & 0.001 & 0.000 & 0.000 & 0.041 & 0.006 & 0.679 \\
\hline $\operatorname{ar} 2 p$ & 0.870 & 0.353 & 0.573 & 0.938 & 0.151 & 0.994 & 0.737 \\
\hline hansen & 0.245 & 0.172 & 0.471 & 0.221 & 0.587 & 0.591 & 1.000 \\
\hline
\end{tabular}

Estimations are all obtained by the Arellano-Bond two-step difference GMM. All instruments include up to four year lags. $\operatorname{ar} 1 p$ and ar $2 p$ are Arellano-Bond test of first order and second order autocorrelation in the errors. hansen is the HansenSargan test of overidentifying restrictions for all instruments. Year and sectoral dummies included in all cases. Country dummies included for the whole sample estimation. P-values are reported for all tests. * indicates significance at $10 \%$, ** significance at $5 \%$ and ${ }^{* * *}$ significance at $1 \%$.

Table 7. Estimation results for nonoperating income instead of financial income based on equation. Period: 2008-2018.

\begin{tabular}{|c|c|c|c|c|c|c|c|}
\hline $\begin{array}{c}\text { Dependent } \\
\text { variable:Cash\&St.Invi,t }\end{array}$ & $\begin{array}{c}\text { All } \\
\text { countries }\end{array}$ & Argentina & Brazil & Chile & Mexico & Peru & Colombia \\
\hline Non-operating Income $e_{i, t}$ & $\begin{array}{l}0.005 \\
(0.008)\end{array}$ & \begin{tabular}{|l|}
0.018 \\
$(0.057)$
\end{tabular} & \begin{tabular}{|l|}
-0.008 \\
$(0.013)$
\end{tabular} & \begin{tabular}{|l|}
0.005 \\
$(0.010)$
\end{tabular} & \begin{tabular}{|l}
$-0.088^{*}$ \\
$(0.046)$
\end{tabular} & \begin{tabular}{|l|}
0.011 \\
$(0.012)$
\end{tabular} & $\begin{array}{l}-0.037 \\
(0.062)\end{array}$ \\
\hline Non-operating Income $e_{i, t-1}$ & $\begin{array}{l}0.022^{* *} \\
(0.009)\end{array}$ & $\begin{array}{l}0.074^{*} \\
(0.038)\end{array}$ & $\begin{array}{l}0.015^{*} \\
(0.009)\end{array}$ & $\begin{array}{l}0.013 \\
(0.010)\end{array}$ & $\mid \begin{array}{l}-0.030 \\
(0.029)\end{array}$ & $\begin{array}{l}0.001 \\
(0.010)\end{array}$ & $\begin{array}{l}-0.020 \\
(0.018)\end{array}$ \\
\hline Non-operating Income $\mathrm{i}_{\mathrm{i}, \mathrm{t}-2}$ & $\begin{array}{l}0.011 \\
(0.011)\end{array}$ & $\begin{array}{l}-0.004 \\
(0.015)\end{array}$ & $\begin{array}{l}0.008 \\
(0.007) \\
\end{array}$ & $\begin{array}{l}0.009 \\
(0.016)\end{array}$ & \begin{tabular}{|l}
0.004 \\
$(0.025)$
\end{tabular} & $\begin{array}{l}-0.001 \\
(0.012)\end{array}$ & \\
\hline N. obs & 6,775 & 643 & 2,581 & 1,408 & 994 & 832 & 334 \\
\hline N. firms & 755 & 67 & 297 & 161 & 109 & 86 & 35 \\
\hline Instruments & 58 & 53 & 53 & 53 & 53 & 53 & 37 \\
\hline $\operatorname{ar} 1 p$ & 0.000 & 0.000 & 0.000 & 0.000 & 0.000 & 0.000 & 0.022 \\
\hline $\operatorname{ar} 2 p$ & 0.436 & 0.669 & 0.647 & 0.506 & 0.253 & 0.547 & 0.967 \\
\hline hansen & 0.204 & 0.479 & 0.215 & 0.745 & 0.382 & 0.258 & 0.973 \\
\hline
\end{tabular}

Estimations are all obtained by the Arellano-Bond two-step difference GMM. All instruments include up to four year lags. ar1p and ar2p are Arellano-Bond test of first order and second order autocorrelation in the errors. hansen is the HansenSargan test of overidentifying restrictions for all instruments. Year and sectoral dummies included in all cases. Country dummies included for the whole sample estimation. P-values are reported for all tests. * indicates significance at $10 \%$, ** significance at $5 \%$ and ${ }^{* * *}$ significance at $1 \%$.

An exercise performed both by Bruno and Shin (2017) and Caballero et al (2016) is to divide the sample between those firms located above and below the median of carry

${ }^{8}$ Finding positive and statistically significant results for nonoperating income rather than financial income in Argentina can be explained by the fact that Argentina had negative real interest rate during most of this second period. 
trades. Both studies find similar results. The latter shows that the positive relation between foreign currency bond issuances and cash holdings is verified for those cases above the sample median of the demeaned spread between local deposit rate and borrowing costs in the United States (their measure of carry trades opportunities).

We do the same in terms of firms located above and below the median value of financial income over revenues for each year and country. Our results go in the same direction. The positive and statistically significant relation for all and Brazilian firms is restricted for those cases belonging above the median. Results disappear for those firms below the median. For the latter, Figure A1 depicts the almost complete lack of relevance of financial income.

Finally, we carry out an exercise that further takes into account the size of the firm. As it was mentioned in Section 2.a, a stylized result in the financialisation literature is the higher involvement of larger firms in financial activities. We therefore divide the sample between firms above and below the median of total assets by year and country. Our results pick that differential effect for Brazil only confirming that it is mainly (large) NFCs from this country those who have been more engaged in profiting from holding and selling assets.

Table 8. Estimation results for financial income based on equation (1). Firms with financial income above the median. Period: 1997-2018.

\begin{tabular}{ll||l||l||l||l||l||l}
\hline \multicolumn{1}{c}{$\begin{array}{c}\text { Dependent } \\
\text { variable:Cash\&St.Invi,t }\end{array}$} & $\begin{array}{c}\text { All } \\
\text { countries }\end{array}$ & Argentina & Brazil & Chile & Mexico & Peru & Colombia \\
\hline Financial Income ${ }_{i, t}$ & $0.120^{* *}$ & -0.113 & $0.171^{* *}$ & -0.004 & -0.109 & 0.211 & -0.433 \\
& $(0.049)$ & $(0.192)$ & $(0.076)$ & $(0.173)$ & $(0.297)$ & $(0.154)$ & $(0.456)$ \\
Financial Income ${ }_{i, t-1}$ & -0.061 & 0.068 & -0.088 & -0.047 & -0.323 & -0.169 & -1.178 \\
& $(0.049)$ & $(0.267)$ & $(0.075)$ & $(0.225)$ & $(0.299)$ & $(0.214)$ & $(1.368)$ \\
Financial Incomei,t-2 & -0.018 & 0.082 & 0.008 & -0.249 & -0.165 & 0.010 & \\
& $(0.037)$ & $(0.240)$ & $(0.039)$ & $(0.176)$ & $(0.167)$ & $(0.136)$ & \\
\hline N. obs & 6,282 & 556 & 2,348 & 1,372 & 885 & 670 & 269 \\
N. firms & 813 & 69 & 347 & 164 & 111 & 82 & 35 \\
Instruments & 70 & 62 & 63 & 64 & 64 & 63 & 48 \\
ar1p & 0.000 & 0.003 & 0.000 & 0.000 & 0.019 & 0.015 & 0.452 \\
ar2p & 0.013 & 0.407 & 0.073 & 0.893 & 0.967 & 0.403 & 0.328 \\
hansen & 0.005 & 0.526 & 0.753 & 0.582 & 0.261 & 0.670 & 1.000 \\
\hline
\end{tabular}

Estimations are all obtained by the Arellano-Bond two-step difference GMM. All instruments include up to four year lags. ar $1 p$ and ar2p are Arellano-Bond test of first order and second order autocorrelation in the errors. hansen is the HansenSargan test of overidentifying restrictions for all instruments. Year and sectoral dummies included in all cases. Country dummies included for the whole sample estimation. P-values are reported for all tests. ${ }^{*}$ indicates significance at $10 \%,{ }^{* *}$ significance at $5 \%$ and ${ }^{* * *}$ significance at $1 \%$.

Table 9. Estimation results for financial income based on equation (1). Firms with financial income below the median. Period: 1997-2018.

\begin{tabular}{|c|c|c|c|c|c|c|c|}
\hline $\begin{array}{c}\text { Dependent } \\
\text { variable:Cash\&St.Invi,t }\end{array}$ & $\begin{array}{c}\text { All } \\
\text { countries }\end{array}$ & Argentina & Brazil & Chile & Mexico & Peru & Colombia \\
\hline Financial Income $e_{i, t}$ & $\begin{array}{l}-0.192^{*} \\
(0.112)\end{array}$ & $\begin{array}{l}-0.198 \\
(0.323)\end{array}$ & \begin{tabular}{|l|}
-0.099 \\
$(0.102)$
\end{tabular} & $\begin{array}{l}0.091 \\
(0.235)\end{array}$ & \begin{tabular}{|l|}
-2.297 \\
$(1.800)$
\end{tabular} & $\begin{array}{l}1.033 \\
(2.401)\end{array}$ & $\begin{array}{l}-0.512 \\
(1.161)\end{array}$ \\
\hline Financial Income $e_{i, t-1}$ & $\begin{array}{l}0.072^{*} \\
(0.041)\end{array}$ & $\begin{array}{l}-0.055 \\
(0.139)\end{array}$ & $\begin{array}{l}0.055 \\
(0.062)\end{array}$ & $\begin{array}{l}0.042 \\
(0.085)\end{array}$ & $\mid \begin{array}{l}0.136 \\
(0.474)\end{array}$ & $\begin{array}{l}-0.375 \\
(0.486)\end{array}$ & $\begin{array}{l}0.287 \\
(0.673)\end{array}$ \\
\hline
\end{tabular}




\begin{tabular}{|c|c|c|c|c|c|c|c|}
\hline Financial Income $e_{i, t-2}$ & $\begin{array}{l}-0.003 \\
(0.034)\end{array}$ & \begin{tabular}{|l}
-0.106 \\
$(0.119)$
\end{tabular} & \begin{tabular}{||l}
0.055 \\
$(0.044)$
\end{tabular} & $\begin{array}{l}-0.027 \\
(0.065)\end{array}$ & \begin{tabular}{||l}
0.232 \\
$(0.356)$
\end{tabular} & \begin{tabular}{|l}
0.124 \\
$(0.150)$
\end{tabular} & \\
\hline N. obs & 5,862 & 520 & 2,324 & 1,069 & 859 & 636 & 263 \\
\hline N. firms & 786 & 66 & 326 & 161 & 105 & 80 & 38 \\
\hline Instruments & 70 & 61 & 63 & 64 & 64 & 63 & 48 \\
\hline $\operatorname{ar} 1 p$ & 0.000 & 0.001 & 0.000 & 0.024 & 0.003 & 0.101 & 0.442 \\
\hline $\operatorname{ar} 2 p$ & 0.483 & 0.792 & 0.642 & 0.142 & 0.511 & 0.335 & 0.477 \\
\hline hansen & 0.005 & 0.817 & 0.013 & 0.263 & 0.215 & 0.340 & 0.991 \\
\hline
\end{tabular}

Estimations are all obtained by the Arellano-Bond two-step difference GMM. All instruments include up to four year lags. ar1p and ar2p are Arellano-Bond test of first order and second order autocorrelation in the errors. hansen is the HansenSargan test of overidentifying restrictions for all instruments. Year and sectoral dummies included in all cases. Country dummies included for the whole sample estimation. P-values are reported for all tests. ${ }^{*}$ indicates significance at $10 \%,{ }^{* *}$ significance at $5 \%$ and ${ }^{* * *}$ significance at $1 \%$.

Table 10. Estimation results for financial income based on equation (1). Firms with total assets above the median. Period: 1997-2018.

\begin{tabular}{|c|c|c|c|c|c|c|c|}
\hline $\begin{array}{c}\text { Dependent } \\
\text { variable:Cash\&St.Invi,t }\end{array}$ & $\begin{array}{c}\text { All } \\
\text { countries }\end{array}$ & Argentina & Brazil & Chile & Mexico & Peru & Colombia \\
\hline Financial Income $e_{i, t}$ & $\begin{array}{l}0.174 * * * \\
(0.042)\end{array}$ & \begin{tabular}{|l}
-0.228 \\
$(26.108)$
\end{tabular} & \begin{tabular}{|l}
$0.203^{* * *}$ \\
$(0.074)$
\end{tabular} & \begin{tabular}{|l|}
0.394 \\
$(0.544)$
\end{tabular} & $\begin{array}{l}0.707 \\
(0.472)\end{array}$ & \begin{tabular}{|l|}
0.000 \\
$(0.238)$
\end{tabular} & \begin{tabular}{|l|}
0.584 \\
$(0.526)$
\end{tabular} \\
\hline Financial Income $e_{i, t-1}$ & $\begin{array}{l}-0.005 \\
(0.030)\end{array}$ & $\begin{array}{l}0.405 \\
(1.685)\end{array}$ & $\begin{array}{l}-0.000 \\
(0.059)\end{array}$ & $\begin{array}{l}0.017 \\
(0.192)\end{array}$ & $\begin{array}{l}-0.069 \\
(0.225)\end{array}$ & $\begin{array}{l}-1.685 \\
(2.429)\end{array}$ & $\begin{array}{l}-0.629 \\
(0.540)\end{array}$ \\
\hline Financial Incomei,t-2 & $\begin{array}{l}0.012 \\
(0.026)\end{array}$ & $\begin{array}{l}-0.275 \\
(6.150)\end{array}$ & $\begin{array}{l}0.024 \\
(0.037) \\
\end{array}$ & $\begin{array}{l}-0.041 \\
(0.169)\end{array}$ & $\begin{array}{l}0.074 \\
(0.109)\end{array}$ & $\begin{array}{l}-0.107 \\
(2.888)\end{array}$ & \\
\hline N. obs & 6,350 & 583 & 2,430 & 1,237 & 931 & 669 & 268 \\
\hline N. firms & 559 & 48 & 234 & 104 & 83 & 49 & 28 \\
\hline Instruments & 70 & 62 & 63 & 64 & 64 & 64 & 48 \\
\hline $\operatorname{ar1p}$ & 0.000 & 0.914 & 0.000 & 0.000 & 0.000 & 0.000 & 0.195 \\
\hline $\operatorname{ar} 2 p$ & 0.945 & 0.979 & 0.941 & 0.209 & 0.047 & 0.299 & 0.384 \\
\hline hansen & 0.888 & 1.000 & 0.656 & 0.539 & 0.311 & 1.000 & 1.000 \\
\hline
\end{tabular}

Estimations are all obtained by the Arellano-Bond two-step difference GMM. All instruments include up to four year lags. ar1p and ar2p are Arellano-Bond test of first order and second order autocorrelation in the errors. hansen is the HansenSargan test of overidentifying restrictions for all instruments. Year and sectoral dummies included in all cases. Country dummies included for the whole sample estimation. P-values are reported for all tests. ${ }^{*}$ indicates significance at $10 \%,{ }^{* *}$ significance at $5 \%$ and ${ }^{* * *}$ significance at $1 \%$.

Table 11. Estimation results for financial income based on equation (1). Firms with total assets below the median. Period: 1997-2018.

\begin{tabular}{|c|c|c|c|c|c|c|c|}
\hline $\begin{array}{c}\text { Dependent } \\
\text { variable:Cash\&St.Inv }{ }_{i, t}\end{array}$ & $\begin{array}{c}\text { All } \\
\text { countries }\end{array}$ & Argentina & Brazil & Chile & Mexico & Peru & Colombia \\
\hline Financial Income $e_{i, t}$ & $\begin{array}{l}0.201^{* * *} \\
(0.074)\end{array}$ & \begin{tabular}{|l|}
1.206 \\
$(1.720)$
\end{tabular} & \begin{tabular}{|l|}
0.112 \\
$(0.077)$
\end{tabular} & \begin{tabular}{|l}
0.164 \\
$(0.178)$
\end{tabular} & \begin{tabular}{|l|l|}
0.243 \\
$(0.341)$
\end{tabular} & \begin{tabular}{|l|}
-0.367 \\
$(0.634)$
\end{tabular} & \begin{tabular}{|l}
0.000 \\
$(0.283)$
\end{tabular} \\
\hline Financial Income $e_{i, t-1}$ & $\begin{array}{l}-0.005 \\
(0.057)\end{array}$ & $\begin{array}{l}-1.033 \\
(1.946)\end{array}$ & $\begin{array}{l}-0.042 \\
(0.071)\end{array}$ & $\begin{array}{l}0.236 \\
(0.195)\end{array}$ & $\begin{array}{l}-0.204 \\
(0.211)\end{array}$ & $\begin{array}{l}0.380 \\
(0.481)\end{array}$ & $\begin{array}{l}0.000 \\
(0.033)\end{array}$ \\
\hline Financial Income $e_{i, t-2}$ & $\begin{array}{l}-0.004 \\
(0.035)\end{array}$ & $\begin{array}{l}-0.456 \\
(0.357)\end{array}$ & $\begin{array}{l}0.005 \\
(0.038)\end{array}$ & $\begin{array}{l}-0.125^{*} \\
(0.068)\end{array}$ & $\begin{array}{l}-0.059 \\
(0.187)\end{array}$ & $\begin{array}{l}-0.122 \\
(0.121)\end{array}$ & \\
\hline N. obs & 5,794 & 493 & 2,242 & 1,204 & 813 & 637 & 264 \\
\hline $\mathrm{N}$. firms & 557 & 46 & 220 & 102 & 76 & 54 & 26 \\
\hline Instruments & 70 & 61 & 63 & 64 & 64 & 60 & 48 \\
\hline $\operatorname{ar} 1 p$ & 0.000 & 0.042 & 0.000 & 0.000 & 0.013 & 0.001 & 0.564 \\
\hline $\operatorname{ar} 2 \mathrm{p}$ & 0.876 & 0.119 & 0.703 & 0.641 & 0.613 & 0.300 & 0.511 \\
\hline hansen & 0.172 & 1.000 & 0.273 & 0.428 & 0.191 & 0.715 & 1.000 \\
\hline
\end{tabular}

Estimations are all obtained by the Arellano-Bond two-step difference GMM. All instruments include up to four year lags. ar1p and ar2p are Arellano-Bond test of first order and second order autocorrelation in the errors. hansen is the HansenSargan test of overidentifying restrictions for all instruments. Year and sectoral dummies included in all cases. Country dummies included for the whole sample estimation. P-values are reported for all tests. ${ }^{*}$ indicates significance at $10 \%,{ }^{* *}$ significance at $5 \%$ and ${ }^{* * *}$ significance at $1 \%$. 


\section{Conclusion}

This article has analyzed the evolution of cash and short-term investments from NFCs belonging to Argentina, Brazil, Chile, Colombia, Mexico and Peru trying to identify, specifically, whether the quest for financial income was a determinant driver or not. Cash holdings typically include interest-bearing assets and different scholars have presented evidence for and against the hypothesis of a financially-driven accumulation by AE NFCs. However, the relevance for emerging markets has been off-radar.

Paradoxically, studies focusing on the specificities adopted by financialisation in emerging economies have highlighted the relatively better opportunities offered by these countries vis-à-vis developed to engage in such activities. Emerging markets typically have higher interest rates than advanced economies that, when coupled with fixed or semi-fixed exchange rates (if the exchange rate is appreciating), allow for carry trades. NFCs also have better opportunities compared to financial firms in order to bypass capital controls. Other studies have also highlighted different cases of NFCs using financial derivatives to speculate rather than hedge against the volatility in national currencies.

Using annual firm-level data for the last 20 years we tested the relation between financial income and cash holdings. Our results indicate that the effect is significant for Brazil only. We find a positive and significant relation between financial income and cash and shortterm investments for the 1997-2018 period with a 1\% increase in financial income associated with $0.2 \%$ increase in those financial assets. It is interesting, however, to note that the surge in cash and short-term investments occurred in the years before the Financial Crisis, remaining constant or slightly decreasing afterwards. The positive relation we found, nevertheless, is valid for the latter period where different studies have indicated better-off conditions to engage, for instance, in carry trades given the increase in capital controls and lower US rate.

In a nutshell, we find signs of financial engagement which on the other hand do not seem to be the reason behind the two-fold increase in cash-to-asset ratio verified for Brazil in the 2000-2007 period.

Further econometric exercises showed that our results for Brazil are further driven by larger firms and those located above the median of financial income. Our findings are robust as well when we compute nonoperating income, rather than financial, which comprises other noninterest-related income such as capital and foreign exchange gains (and losses). Positive results for Brazil in the 2008-2018 period were maintained along with the inclusion of Argentina.

Besides this, we can point some limits of this research and qualify some of our results. First, even in the case of Brazilian NFCs where we found evidence of active engagement in financial activities, the proportion of financial income over total revenues has been fairly low: $3.2 \%$ for those firms above the median. Second, in this paper we focused on cash and short-term investments only leaving aside other financial assets which may be an indication of financial engagement. Examples of these assets can be those of longer maturity which are classified in our database as 'Other Assets', a residual category which also includes nonfinancial assets. Third, our database presents incomplete information in order to individually identify cash, on the one hand, and short-term investments, on the 
other. This distinction might be of relevance for the 2008-2018 period where the aggregate measure was stable in some countries, but probably changes in the composition were experienced. Therefore, further research is needed in one-by-one cases with the help of the financial statements and their notes. Future research should also try to provide other explanations for the increase in cash holding from Latin American firms. 


\section{References}

Abeles, M., Pérez Caldentey, E., \& Valdecantos, S. (Eds.). (2018). Estudios sobre financierización en América Latina. CEPAL.

Acharya, V. V., Almeida, H., \& Campello, M. (2007). Is cash negative debt? A hedging perspective on corporate financial policies. Journal of Financial Intermediation, 16(4), 515-554.

Al-Najjar, B. (2013). The financial determinants of corporate cash holdings: Evidence from some emerging markets. International business review, 22(1), 77-88.

Anderson, T. W., \& Hsiao, C. (1981). Estimation of dynamic models with error components. Journal of the American statistical Association, 76(375), 598-606. https://doi.org/10.1080/01621459.1981.10477691

Arellano, M., \& Bond, S. (1991). Some tests of specification for panel data: Monte Carlo evidence and an application to employment equations. The review of economic studies, 58(2), 277-297. https://doi.org/10.2307/2297968

Arellano, M., \& Bover, O. (1995). Another look at the instrumental variable estimation of error-components models. Journal of econometrics, 68(1), 29-51. https://doi.org/10.1016/0304-4076(94)01642-D

Auvray, T., \& Rabinovich, J. (2019). The financialisation-offshoring nexus and the capital accumulation of US nonfinancial firms. Cambridge Journal of Economics, 43(5), 1183-1218. https://doi.org/10.1093/cje/bey058

Avdjiev, S., Chui, M. K., \& Shin, H. S. (2014). Non-financial corporations from emerging market economies and capital flows. BIS Quarterly Review, 67-77.

Bates, T. W., Kahle, K. M., \& Stulz, R. M. (2009). Why do US firms hold so much more cash than they used to? The journal of finance, 64(5), 1985-2021. https://doi.org/10.1111/j.1540-6261.2009.01492.x

Bellas, D., Papaioannou, M. G., \& Petrova, I. (2010). Determinants of emerging market sovereign bond spreads. En C. A. Primo Braga \& G. A. Vincelette, Sovereign Debt and the Financial Crisis: Will This Time Be Different? (pp. 77-101). The World Bank.

Blundell, R., \& Bond, S. (1998). Initial conditions and moment restrictions in dynamic panel data models. Journal of Econometrics, 87(1), 115-143. https://doi.org/10.1016/S0304-4076(98)00009-8

Bond, S., Elston, J. A., Mairesse, J., \& Mulkay, B. (2003). Financial factors and investment in Belgium, France, Germany, and the United Kingdom: A comparison using company panel data. Review of economics and statistics, 85(1), 153-165. https://doi.org/10.1162/003465303762687776

Bonizzi, B. (2013). Financialization in developing and emerging countries: A survey. International Journal of Political Economy, 42(4), 83-107. https://doi.org/10.2753/IJP0891-1916420405

Bortz, P. G., \& Kaltenbrunner, A. (2018). The international dimension of financialization in developing and emerging economies. Development and Change, 49(2), 375-393. https://doi.org/10.1111/dech.12371

Bruno, V., \& Shin, H. S. (2017). Global dollar credit and carry trades: A firm-level analysis. The Review of Financial Studies, 30(3), 703-749. https://doi.org/10.1093/rfs/hhw099

Caballero, J., Panizza, U., \& Powell, A. (2016). The second wave of global liquidity: Why are firms acting like financial intermediaries? IDB Working Paper, 641. 
Cadsby, C., Frank, M. Z., \& Maksimovic, V. (1990). Pooling, Separating and Semiseparating Equilibria in Financial Markets: Some Experimental Evidence. The review of Financial Studies, 3(3), 315-342.

Cantor, R., \& Packer, F. (1996). Determinants and impact of sovereign credit ratings. Economic Policy Review, 2(2). https://doi.org/10.2139/ssrn.1028774

Conti, B. M., Prates, D. M., \& Plihon, D. (2014). A hierarquia monetária e suas implicações para as taxas de câmbio e de juros e a política econômica dos países periféricos. Economia e Sociedade, 23(2), 341.

Crotty, J. (2005). The neoliberal paradox: The impact of destructive product market competition and 'modern' financial markets on nonfinancial corporation performance in the neoliberal era. En G. Epstein (Ed.), Financialization and the world economy (pp. 77-110). Edward Elgar.

Davis, L. E. (2016). Identifying the "financialization" of the nonfinancial corporation in the US economy: A decomposition of firm-level balance sheets. Journal of Post Keynesian Economics, 39(1), 115-141. https://doi.org/10.1080/01603477.2015.1116370

Davis, L. E. (2017). Financialization and the non-financial corporation: An investigation of firm-level investment behavior in the United States. Metroeconomica, 69(1), 270307. https://doi.org/10.1111/meca.12179

Davis, L. E. (2018). Financialization, Shareholder Orientation and the Cash Holdings of US Corporations. Review of Political Economy, 1-27. https://doi.org/10.1080/09538259.2018.1429147

Demir, F. (2007). The rise of rentier capitalism and the financialization of real sectors in developing countries. Review of Radical Political Economics, 39(3), 351-359. https://doi.org/10.1177/0486613407305283

Demir, F. (2009). Financial liberalization, private investment and portfolio choice: Financialization of real sectors in emerging markets. Journal of Development Economics, 88(2), 314-324. https://doi.org/10.1016/j.jdeveco.2008.04.002

Economic Commission for Latin America and the Caribbean. (2014). Estudio Económico de América Latina. United Nations.

Eichner, A. (1976). The megacorp and oligopoly. Cambridge University Press.

Farhi, M., \& Borghi, R. A. Z. (2009). Operations with financial derivatives of corporations from emerging economies. Estudos Avançados, 23(66), 169-188. https://doi.org/10.1590/S0103-40142009000200013

Fernández, A., Klein, M. W., Rebucci, A., Schindler, M., \& Uribe, M. (2016). Capital control measures: A new dataset. IMF Economic Review, 64(3), 548-574.

Frank, M. Z., \& Goyal, V. K. (2008). Trade-Off and Pecking Order Theories of Debt. En B. E. Eckbo (Ed.), Handbook of Empirical Corporate Finance (pp. 135-202). Elsevier. https://doi.org/10.1016/B978-0-444-53265-7.50004-4

Froud, J., Johal, S., Leaver, A., \& Williams, K. (2006). Financialization and strategy: Narrative and numbers. Routledge.

Hadlock, C. J., \& Pierce, J. R. (2010). New evidence on measuring financial constraints: Moving beyond the KZ index. The Review of Financial Studies, 23(5), 1909-1940.

Hecht, J. (2014). Is net stock issuance relevant to capital formation? Comparing heterodox models of firm-level capital expenditures across the advanced and largest 
developing economies. Cambridge Journal of Economics, 38(5), 1171-1206. https://doi.org/10.1093/cje/bet070

International Monetary Fund. (2015). Recent investment weakness in Latin America: Is there a Puzzle? En Economic Outlook-Western Hemisfere (pp. 59-73).

Kaltenbrunner, A. (2015). A post Keynesian framework of exchange rate determination: A Minskyan approach. Journal of Post Keynesian Economics, 38(3), 426-448.

Karwowski, E., \& Stockhammer, E. (2017). Financialisation in emerging economies: A systematic overview and comparison with Anglo-Saxon economies. Economic and Political Studies, 5(1), 60-86. https://doi.org/10.1080/20954816.2016.1274520

Khanna, T., \& Yafeh, Y. (2007). Business groups in emerging markets: Paragons or parasites? Journal of Economic literature, 45(2), 331-372. https://doi.org/10.1257/jel.45.2.331

Krippner, G. R. (2005). The financialization of the American economy. Socio-Economic Review, 3(2), 173-208. https://doi.org/10.1093/SER/mwi008

Krippner, G. R. (2011). Capitalizing on crisis. Harvard University Press.

Lavoie, M. (1992). Foundations of Post-Keynesian Economic Analysis. Edward Elgar Publishing.

Magdoff, H., \& Sweezy, P. M. (1987). Stagnation and the financial explosion. NYU Press.

Manuelito, S., \& Jiménez, L. F. (2015). Stylized features of the investment-growth connection in Latin America, 1980-2012. CEPAL Review, 115, 7-22.

McCauley, R. N., Upper, C., \& Villar, A. (2013). Emerging market debt securities issuance in offshore centres. BIS Quarterly Review, 22-23.

Myers, S. C., \& Majluf, N. S. (1984). Corporate financing and investment decisions when firms have information that investors do not have. Journal of Financial Economics, 13(2), 187-221. https://doi.org/10.1016/0304-405X(84)90023-0

Neumann, D. (2016, abril 15). Empresarios explicam por que defiendem saída de Dilma. Valor Económico.

Nickell, S. (1981). Biases in dynamic models with fixed effects. Econometrica: Journal of the Econometric Society, 1417-1426. https://doi.org/10.2307/1911408

Opler, T., Pinkowitz, L., Stulz, R., \& Williamson, R. (1999). The determinants and implications of corporate cash holdings. Journal of financial economics, 52(1), 3-46.

Orhangazi, Ö. (2008). Financialisation and capital accumulation in the non-financial corporate sector: A theoretical and empirical investigation on the US economy: 1973-2003. Cambridge Journal of Economics, 32(6), 863-886. https://doi.org/10.1093/cje/ben009

Pérez Artica, R., Brufman, L., \& Saguí, N. (2018). Why do Latin American firms hold so much more cash than they used to? Contabilidade e Finanças, 29(78), 1985-2021. https://doi.org/10.1590/1808-057x201805660

Pindado, J., \& Requejo, I. (2015). Panel data: A methodology for model specification and testing. Wiley Encyclopedia of Management, 4, 1-8. https://doi.org/10.1002/9781118785317.weom040013

Pinkowitz, L., Stulz, R. M., \& Williamson, R. (2015). Do US firms hold more cash than foreign firms do? The Review of Financial Studies, 29(2), 309-348. https://doi.org/10.1093/rfs/hhv064 
Powell, J. (2013). Subordinate financialisation: A study of Mexico and its non-financial corporations [PhD Thesis]. SOAS, University of London.

Rabinovich, J. (2019). The financialisation of the nonfinancial corporation. A critique to the financial turn of accumulation hypothesis. Metroeconomica, 70(4), 738-775. https://doi.org/10.1111/meca.12251

Roodman, D. (2009). How to do xtabond2: An introduction to difference and system GMM in Stata. Stata Journal, 9(1), 86-136. https://doi.org/10.1177/1536867X0900900106

Rossi Júnior, J. L. (2013). Hedging, selective hedging, or speculation? Evidence of the use of derivatives by Brazilian firms during the financial crisis. Journal of Multinational Financial Management, 23(5), 415-433. https://doi.org/10.1016/j.mulfin.2013.08.004

Seo, H.-J., Kim, H. S., \& Kim, J. (2016). Does Shareholder Value Orientation or Financial Market Liberalization Slow Down Korean Real Investment? Review of Radical Political Economics, 48(4), 633-660. https://doi.org/10.1177/0486613415603159

Shin, H. S., \& Zhao, L. (2013). Firms as surrogate intermediaries: Evidence from emerging economies [Manuscript]. Princeton University.

Stockhammer, E. (2004). Financialisation and the slowdown of accumulation. Cambridge Journal of Economics, 28(5), 719-741. https://doi.org/10.1093/cje/beh032

Tomaskovic-Devey, D., Lin, K.-H., \& Meyers, N. (2015). Did financialization reduce economic growth? Socio-Economic Review, 13(3), 525-548. https://doi.org/10.1093/ser/mwv009

Tori, D., \& Onaran, Ö. (2018a). The effects of financialisation and financial development on investment: Evidence from firm-level data in Europe. Socio-Economic Review, forthcoming. https://doi.org/10.1093/ser/mwy044

Tori, D., \& Onaran, Ö. (2018b). The effects of financialization on investment: Evidence from firm-level data for the UK. Cambridge Journal of Economics, 42(5), 1393-1416. https://doi.org/10.1093/cje/bex085

Torija Zane, E., \& Gottschalk, R. (2018). Patrones financieros y de inversión en América Latina desde la perspectiva del comportamiento empresarial. En M. Abeles, E. Pérez Caldentey, \& S. Valdecantos (Eds.), Estudios sobre financierización en América Latina.

Windmeijer, F. (2005). A finite sample correction for the variance of linear efficient twostep GMM estimators. Journal of econometrics, 126(1), 25-51. https://doi.org/10.1016/j.jeconom.2004.02.005

Wood, A. (1975). A theory of profits. Cambridge University Press.

Zeidan, R., \& Rodrigues, B. (2013). The failure of risk management for nonfinancial companies in the context of the financial crisis: Lessons from Aracruz Celulose and hedging with derivatives. Applied Financial Economics, 23(3), 241-250. https://doi.org/10.1080/09603107.2012.714070 